This is the final peer-reviewed accepted manuscript of:

Leoni A, Frosini M, Locatelli A, Micucci M, Carotenuto C, Durante M, Cosconati S, Budriesi R.

4-Imidazo[2,1-b]thiazole-1,4-DHPs and neuroprotection: preliminary study in hits searching.

Eur J Med Chem. 2019 May 1;169:89-102.

The final published version is available online at: DOI: 10.1016/j.ejmech.2019.02.075

Rights / License:

The terms and conditions for the reuse of this version of the manuscript are specified in the publishing policy. For all terms of use and more information see the publisher's website.

This item was downloaded from IRIS Università di Bologna (https://cris.unibo.it/)

When citing, please refer to the published version. 


\title{
4-Imidazo[2,1-b]thiazole-1,4-DHPs and neuroprotection: Preliminary study in hits searching ${ }^{\text {h }}$
}

\author{
Alberto Leoni ${ }^{\mathrm{a}}$, Maria Frosini ${ }^{\mathrm{b}}$, Alessandra Locatelli ${ }^{\mathrm{a}}$, Matteo Micucci ${ }^{\mathrm{a}}$, Claudio Carotenuto ${ }^{\mathrm{b}}$, Miriam Durante ${ }^{\mathrm{b}}$, \\ Sandro Cosconati ${ }^{\mathrm{c}}$, Roberta Budriesi ${ }^{\mathrm{a}, *}$ \\ a Department of Pharmacy and Biotecnology (FaBit), Alma Mater Studiorum-University of Bologna, Via Belmeloro 6, 40126 Bologna, Italy \\ b Department of Life Science, Università degli Studi di Siena, Via A. Moro 2, 53100, Siena, Italy \\ ${ }^{c}$ DiSTABiF, Università della Campania Luigi Vanvitelli, 81100, Caserta, Italy
}

\section{A R T I C L E I N F O}

Article history:

Received 8 November 2018

Received in revised form 21 February 2019

Accepted 27 February 2019

Available online xxx

\section{Keywords:}

Imidazo[2,1- $b]$ thiazoles

1,4-Dihydropyridines

Neuroprotection

Calcium channels blockers

\section{A B S T R A C T}

In the present work we describe the synthesis, characterization and evaluation of neuroprotective effects of a focused library of 4-imidazo[2,1-b]thiazole-1,4-dihydropyridines. Furthermore, the new dihydropyridines were subjected to functional in vitro assays in cardiac tissues and vascular smooth muscle to determine their possible selectivity in counteracting the effects of neurodegeneration. In particular the strategy adopted for designing the compounds involves the imidazo[2,1-b]thiazole nucleus. The observed properties show that substituents at $\mathrm{C} 2$ and $\mathrm{C} 6$ of the bicyclic scaffold are able to influence the cardiovascular parameters and the neuroprotective activity. In comparison to nifedipine, a set of derivatives such as compound $\mathbf{6}$, showed a neuroprotective profile of particular interest.

(C) 2019 .

\section{Introduction}

Neuroprotection is referred to a cluster of strategies aimed at preventing, inhibiting or counteracting progressive neurons loss. This event occurs in both chronic and acute neurodegenerative disorders: Alzheimer, Parkinson, amyotrophic lateral sclerosis (ALS) or ischemic and hemorrhagic stroke [1-3]. Despite their different etiologies and clinical manifestations, these neurodegenerative diseases may share common biological pathways, such as neuronal excitotoxicity and the downstream consequences of calcium overload [4]. In excitotoxicity excessive glutammate induces glutammate receptors activation, including $N$-methyl-D-aspartic acid (NMDA), $\alpha$-amino-3-hydroxy-5-methylisoxazole-4-propionate (AMPA) and kainic acid (KA) subtypes, thereby increasing $\mathrm{Ca}^{2+}$ entry into neurons through specific channels. As a consequence, excitotoxicity occurs resulting in neuronal dysfunction, damage or even death. Intracellular $\mathrm{Ca}^{2+}$ influx depends mainly on two events: influx from the extracellular space (due to membrane depolarization, resulting in the opening of voltage-dependent $\mathrm{Ca}^{2+}$ channels, and the activation of the NMDA receptor-gated channels) and intracellular $\mathrm{Ca}^{2+}$ release. Free $\mathrm{Ca}^{2+}$ concentration fluctuations in several cellular sub-compartments con-

\footnotetext{
This paper is dedicated to Professor Alberto Chiarini on the occasion of his $70^{\text {th }}$ birthday.

* Corresponding author.

Email address: roberta.budriesi@unibo.it (R. Budriesi)
}

stitute a universal signaling system, able to modulate most of the cellular functions, including apoptosis, through the involvement of calcium-dependent effectors. Increased cytosolic $\mathrm{Ca}^{2+}$ levels trigger signaling cascades, inducing neural dysfunction and death, thus the administration of $\mathrm{Ca}^{2+}$ chelating agents or calcium channels blockers may help restore homeostasis and promote neuronal survival [5]. In addition, free intracellular $\mathrm{Ca}^{2+}$ release activates nitric oxide synthase (NOS), resulting in an increase of oxygen and nitrogen free radicals, which augments oxidative stress, producing DNA, lipids and proteins damage. In particular, nitric oxide, through the S-nitrosylation process, favors the accumulation of misfolded proteins which often develop aggregates in Alzheimer's, Parkinson's, and other neurodegenerative diseases. Furthermore, S-nitrosylation may alter mitochondrial function, contributing to neuronal dysfunction. In regards to the therapeutic neuroprotective strategies, several steps of the excitotoxic cascade represent possible molecular targets. Therefore, NMDA antagonists, calcium channels blockers [6], neuronal nitric oxide synthase inhibitors, misfolding proteins inhibitors, may be considered potential therapeutic agents for neuroprotection. In this paper, we focused on calcium channels antagonists. Calcium channels blockers include a wide variety of drugs. From a medicinal chemistry point of view, they can be classified into three main groups: 1,4-dihydropyridines (1,4-DHPs) whose lead compound is nifedipine, phenylalkylamines with verapamil being the lead compound, and benzothiazepines whose lead compound is represented by diltiazem. Verapamil and diltiazem show a great activity towards the heart, therefore 
they are mainly used for arrhythmias treatment, while nifedipine, due to its antagonism towards peripheral L-type calcium channels, is generally used for hypertension treatment. In particular, we focused our attention on 1,4-DHPs showing a higher affinity towards L-type calcium channels [7]. These channels are key proteins mediating calcium entry into electrically excitable cells in response to membrane depolarization, and they are formed by five different channel subunits $\left(\alpha_{1}\right.$, $\alpha_{2}, \beta, \gamma, \delta$ ) of which $\alpha_{1}$ represents the central pore-forming channel unit, responsible for calcium entry regulation $[6,8,9]$. Different $\alpha_{1}$ subunits have been identified and characterized in different $\mathrm{L}$ type calcium channels, which include four different isoforms: Cav1.1, mainly restricted to skeletal muscle; Cav1.2 and Cav1.3 mainly expressed in heart and brain tissues; Cav1.4 mainly found in the retina where it is required for $\mathrm{Ca}^{2+}$ signals necessary for transmission of visual stimuli. The most efficient approach aimed at inhibiting neurodegeneration is based on "multi target direct ligands" (MTDL) able to hit several steps of the excitotoxic cascade. Nifedipine and other calcium antagonists should be considered MTDL as they exert neuroprotective activities through a complex mechanism involving calcium channels inhibition and other biological effects [10]. Many derivatives featuring the 1,4-DHPs pharmacophore have been shown to bind to several targets $[7,11]$, however they do not discriminate or show poor selectivity between the brain and cardiovascular calcium channels. This feature impedes a clinical application [12]. For this reason, it is important to identify nifedipine structural analogs that elicit high functional activity $v s$ brain L-type calcium channels with low interaction with peripheral calcium channels. In previous works, we demonstrated that specific nifedipine analogs are able to selectively bind different isoforms of cardiovascular calcium channels [13] and that specific modifications increase the affinity for Cav1.2 and Cav1.3 in heart and brain [14]. The results obtained by a ligand-based design approach prompted the design and synthesis of new 1,4-DHPs bearing in position 4 the same imidazo[2,1-b]thiazole scaffold with different substituents to find selective ligands able to limit brain damage resulting from various pathological conditions without interfering with peripheral functions. Herein we report the evaluation of neuroprotection effects of a small library of 4-imidazo[2,1-b]thiazole-1,4-DHPs along with its peripheral functional characterization. In particular, in the latest 1,4-DHPs structural modifications were addressed to those substituents of the 5-(1,4-dihydropyridine-4-yl)imidazo[2,1- $b]$ thiazole core which from the previous assessments have emerged as determinants to influence the activity from the previous assessments (Fig. 1).

\section{Chemistry}

The synthesis of the new 4-imidazo[2,1- $b]$ thiazole-1,4-dihydropyridines: 10-24, 30, 32, 34-39 (Scheme 2, Table 1) was accomplished by means of the well-known Hantzsch reaction [15]: one-pot condensation of the appropriate $\beta$-ketoester, methylacetatoacetate or ethylacetoacetate or allylacetoacetate with the opportune aldehydes $4 \mathbf{a}-\mathbf{w}$ in a solution of aqueous ammonia and isopropyl alcohol. After standard purification, the 1,4-DHPs were obtained with a range of $10-35 \%$ yield. The new starting aldehydes $4 \mathbf{a}, \mathbf{c}-\mathbf{e}$ and the aldehyde $\mathbf{4 b}$ [16] (Scheme 1) were obtained by means of the Vilsmeier reaction on the new compounds 3a-e prepared in turn from the appropriate 2-aminoderivative (1a-b) and the bromoketones (2a,c-e), both commercially available, or prepared according to the literature (2b) [17]. The other starting materials $\mathbf{4 f - w}$ [16-25] were prepared according to the literature. All the structures of final products were confirmed with Infrared and Nuclear Magnetic Resonance spectra. The new compounds synthesized gave ${ }^{1} \mathrm{H}$ NMR and ${ }^{13} \mathrm{C}$ NMR spectra in agreement with the assigned structures and showed common features as regards the 1,4-DHP moiety.

\section{Pharmacology \\ 3.1. Neuroprotection assessment}

Disturbances in calcium homeostasis is involved in the progression of many chronic neurodegenerative diseases such as Alzheimer Disease (AD) [27], Parkinson Disease (PD) [28,29] as well as brain ischemia [30] and calcium channel blockers might exert neuroprotection $[28,29,31]$. Thus, the neuroprotective effects of 1,4-DHP derivatives 5-39, in different models of excitotoxicity-mediate injury were studied by using human U-373 MG astrocytoma- and human SH SY5Y neuroblastoma-cells, as in vitro model system of astrocytes and neurons, respectively.

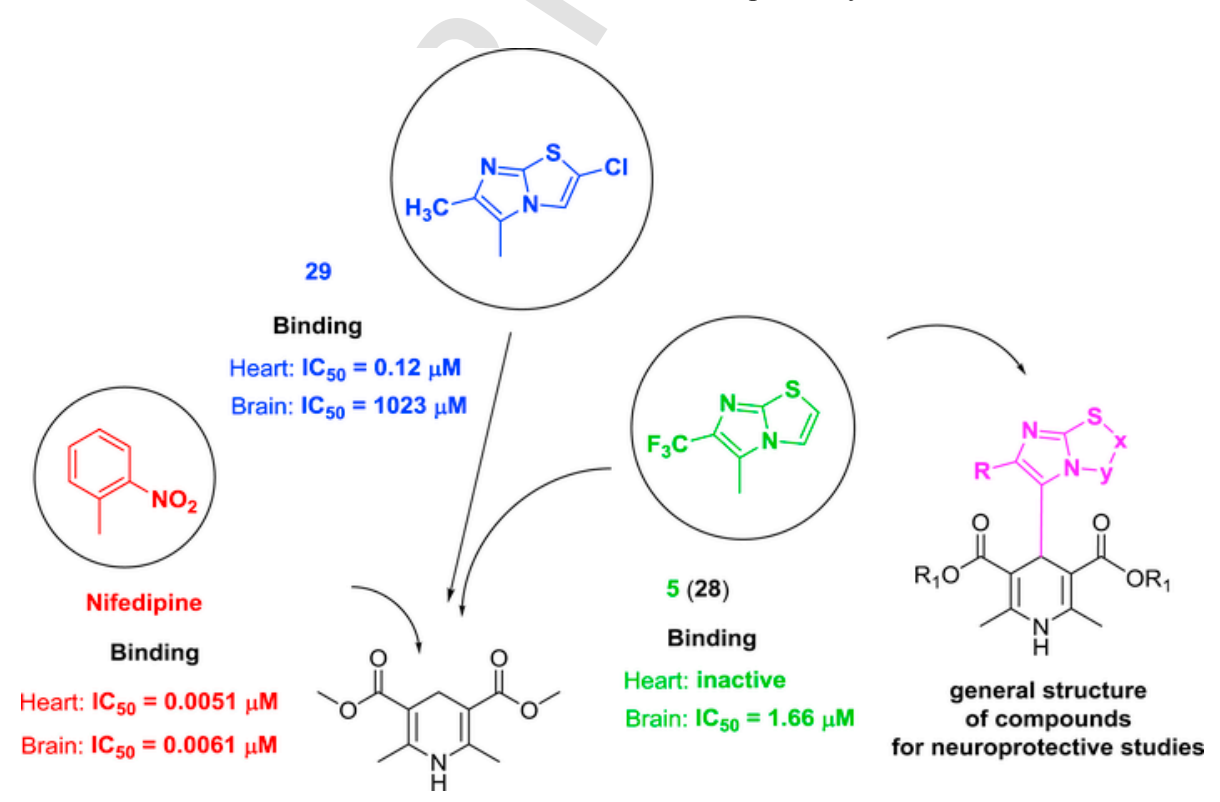

Fig. 1. Nifedipine and the general structure of studied compounds. All data and compounds $\mathbf{2 8 ,} \mathbf{2 9}$ from ref. 14. 
Table 1

1,4-DHPs 5-39.

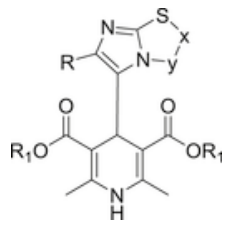

\begin{tabular}{|c|c|c|c|c|}
\hline Compd & $\begin{array}{l}\text { Starting } \\
\text { Aldehydes }\end{array}$ & $x-y$ & $\mathrm{R}$ & $\mathrm{R}_{1}$ \\
\hline $5^{\mathrm{a}}$ & & $\mathrm{HC}=\mathrm{CH}$ & $\mathrm{CF}_{3}$ & $\mathrm{CH}_{3}$ \\
\hline $6^{\mathrm{a}}$ & & $\begin{array}{l}\mathrm{H}_{3} \mathrm{CC}= \\
\mathrm{CH}\end{array}$ & $\mathrm{CF}_{3}$ & $\mathrm{CH}_{3}$ \\
\hline $7^{\mathrm{a}}$ & & $\mathrm{HC}=\mathrm{CCH}_{3}$ & $\mathrm{C}_{6} \mathrm{H}_{5}$ & $\mathrm{CH}_{3}$ \\
\hline $8^{\mathrm{b}}$ & & $\mathrm{HC}=\mathrm{CH}$ & $4-\left(\mathrm{CF}_{3}\right)-\mathrm{C}_{6} \mathrm{H}_{4}$ & $\mathrm{CH}_{3}$ \\
\hline $9^{b}$ & & $\mathrm{HC}=\mathrm{CH}$ & $4-\left(\mathrm{OCF}_{3}\right)-\mathrm{C}_{6} \mathrm{H}_{4}$ & $\mathrm{CH}_{3}$ \\
\hline 10 & $4 a$ & $\mathrm{BrC}=\mathrm{CH}$ & $4-\left(\mathrm{OCF}_{3}\right)-\mathrm{C}_{6} \mathrm{H}_{4}$ & $\mathrm{C}_{2} \mathrm{H}_{5}$ \\
\hline 11 & $4 f^{d}$ & $\mathrm{HC}=\mathrm{CH}$ & 2-(F)- $\mathrm{C}_{6} \mathrm{H}_{4}$ & $\mathrm{C}_{2} \mathrm{H}_{5}$ \\
\hline 12 & $4 g^{e}$ & $\mathrm{HC}=\mathrm{CH}$ & $4-(\mathrm{F})-\mathrm{C}_{6} \mathrm{H}_{4}$ & $\mathrm{C}_{2} \mathrm{H}_{5}$ \\
\hline 13 & $4 h^{\mathrm{e}}$ & $\begin{array}{l}\mathrm{H}_{3} \mathrm{CC}= \\
\mathrm{CH}\end{array}$ & 4-(F) $-\mathrm{C}_{6} \mathrm{H}_{4}$ & $\mathrm{C}_{2} \mathrm{H}_{5}$ \\
\hline 14 & $4 i^{d}$ & $\mathrm{ClC}=\mathrm{CH}$ & $4-(\mathrm{F})-\mathrm{C}_{6} \mathrm{H}_{4}$ & $\mathrm{C}_{2} \mathrm{H}_{5}$ \\
\hline 15 & $4 j^{f}$ & $\mathrm{BrC}=\mathrm{CH}$ & 4-(F) $-\mathrm{C}_{6} \mathrm{H}_{4}$ & $\mathrm{C}_{2} \mathrm{H}_{5}$ \\
\hline 16 & $4 k^{d}$ & $\mathrm{HC}=\mathrm{CH}$ & $3,4-(\mathrm{F})_{2}-\mathrm{C}_{6} \mathrm{H}_{3}$ & $\mathrm{C}_{2} \mathrm{H}_{5}$ \\
\hline 17 & $4 l^{\mathrm{d}}$ & $\mathrm{HC}=\mathrm{CH}$ & $2,6-(\mathrm{F})_{2}-\mathrm{C}_{6} \mathrm{H}_{3}$ & $\mathrm{C}_{2} \mathrm{H}_{5}$ \\
\hline 18 & $4 m^{d}$ & $\mathrm{HC}=\mathrm{CH}$ & $2,4,5-(\mathrm{F})_{3}-\mathrm{C}_{6} \mathrm{H}_{2}$ & $\mathrm{C}_{2} \mathrm{H}_{5}$ \\
\hline 19 & $4 n^{g}$ & $\mathrm{HC}=\mathrm{CH}$ & $4-(\mathrm{Cl})-\mathrm{C}_{6} \mathrm{H}_{4}$ & $\mathrm{C}_{2} \mathrm{H}_{5}$ \\
\hline 20 & $40^{\mathrm{h}}$ & $\mathrm{ClC}=\mathrm{CH}$ & $4-(\mathrm{Cl})-\mathrm{C}_{6} \mathrm{H}_{4}$ & $\mathrm{C}_{2} \mathrm{H}_{5}$ \\
\hline 21 & $4 p^{i}$ & $\mathrm{ClC}=\mathrm{CH}$ & 4- $\left(\mathrm{NO}_{2}\right)-\mathrm{C}_{6} \mathrm{H}_{4}$ & $\mathrm{C}_{2} \mathrm{H}_{5}$ \\
\hline 22 & $4 q^{d}$ & $\mathrm{FC}=\mathrm{CH}$ & 4-( $\left(\mathrm{NO}_{2}\right)-\mathrm{C}_{6} \mathrm{H}_{4}$ & $\mathrm{C}_{2} \mathrm{H}_{5}$ \\
\hline 23 & $4 r^{j}$ & $\mathrm{ClC}=\mathrm{CH}$ & $5-\left(\mathrm{NO}_{2}\right) 2,4-(\mathrm{Cl})_{2} \mathrm{C}_{6} \mathrm{H}_{2}$ & $\mathrm{C}_{2} \mathrm{H}_{5}$ \\
\hline 24 & $4 \mathrm{~s}^{\mathrm{j}}$ & $\mathrm{H}_{5} \mathrm{C}_{2} \mathrm{C}=\mathrm{CH}$ & 5- $\left(\mathrm{NO}_{2}\right) 2,4-(\mathrm{Cl})_{2} \mathrm{C}_{6} \mathrm{H}_{2}$ & $\mathrm{C}_{2} \mathrm{H}_{5}$ \\
\hline $25^{\mathrm{a}}$ & & $\mathrm{HC}=\mathrm{CH}$ & $2-\left(\mathrm{OCH}_{3}\right) \mathrm{C}_{6} \mathrm{H}_{4}$ & $\mathrm{CH}_{3}$ \\
\hline $26^{\mathrm{a}}$ & & $\mathrm{HC}=\mathrm{CH}$ & $3-\left(\mathrm{OCH}_{3}\right) \mathrm{C}_{6} \mathrm{H}_{4}$ & $\mathrm{CH}_{3}$ \\
\hline $27^{\mathrm{a}}$ & & $\mathrm{HC}=\mathrm{CH}$ & $2,5-\left(\mathrm{OCH}_{3}\right)_{2} \mathrm{C}_{6} \mathrm{H}_{3}$ & $\mathrm{CH}_{3}$ \\
\hline $28^{\mathrm{a}}$ & & $\mathrm{ClC}=\mathrm{CH}$ & $2,5-\left(\mathrm{OCH}_{3}\right)_{2} \mathrm{C}_{6} \mathrm{H}_{3}$ & $\mathrm{CH}_{3}$ \\
\hline $29^{\mathrm{a}}$ & & $\mathrm{ClC}=\mathrm{CH}$ & $\begin{array}{l}\text { 6-( }\left(\mathrm{NO}_{2}\right)-2,5-\left(\mathrm{OCH}_{3}\right)_{2} \\
-\mathrm{C}_{6} \mathrm{H}_{2}\end{array}$ & $\mathrm{CH}_{3}$ \\
\hline 30 & $4 t^{k}$ & $\mathrm{HC}=\mathrm{CH}$ & $\begin{array}{l}4-\left(\mathrm{NO}_{2}\right) 2,5-\left(\mathrm{OCH}_{3}\right)_{2} \\
-\mathrm{C}_{6} \mathrm{H}_{2}\end{array}$ & $\mathrm{CH}_{2}=\mathrm{CHCH}_{2}$ \\
\hline $31^{\mathrm{a}}$ & & $\mathrm{HC}=\mathrm{CH}$ & $\begin{array}{l}\text { 4-( }\left(\mathrm{NO}_{2}\right)^{2,5}-\left(\mathrm{OCH}_{3}\right)_{2} \\
-\mathrm{C}_{6} \mathrm{H}_{2}\end{array}$ & $\mathrm{CH}_{3}$ \\
\hline 32 & $4 b^{1}$ & $\mathrm{HC}=\mathrm{CH}$ & $\begin{array}{l}5-(\mathrm{Br}) 2,4-\left(\mathrm{OCH}_{3}\right)_{2} \\
-\mathrm{C}_{6} \mathrm{H}_{2}\end{array}$ & $\mathrm{CH}_{3}$ \\
\hline $33^{\mathrm{c}}$ & & $\mathrm{HC}=\mathrm{CH}$ & $2,5-\left(\mathrm{OCH}_{3}\right)_{2}-\mathrm{C}_{6} \mathrm{H}_{3}$ & $\mathrm{C}_{2} \mathrm{H}_{5}$ \\
\hline 34 & $4 u^{m}$ & $\begin{array}{l}\mathrm{H}_{3} \mathrm{CC}= \\
\mathrm{CH}\end{array}$ & $2,5-\left(\mathrm{OCH}_{3}\right)_{2}-\mathrm{C}_{6} \mathrm{H}_{3}$ & $\mathrm{C}_{2} \mathrm{H}_{5}$ \\
\hline 35 & $4 c$ & $\mathrm{BrC}=\mathrm{CH}$ & $2,5-\left(\mathrm{OCH}_{3}\right)_{2}-\mathrm{C}_{6} \mathrm{H}_{3}$ & $\mathrm{C}_{2} \mathrm{H}_{5}$ \\
\hline 36 & $4 d$ & $\mathrm{BrC}=\mathrm{CH}$ & $3,4-\left(\mathrm{OCH}_{3}\right)_{2}-\mathrm{C}_{6} \mathrm{H}_{3}$ & $\mathrm{C}_{2} \mathrm{H}_{5}$ \\
\hline 37 & $4 e$ & $\mathrm{BrC}=\mathrm{CH}$ & $3,5-\left(\mathrm{OCH}_{3}\right)_{2}-\mathrm{C}_{6} \mathrm{H}_{3}$ & $\mathrm{C}_{2} \mathrm{H}_{5}$ \\
\hline 38 & $4 v^{i}$ & $\begin{array}{l}\mathrm{H}_{3} \mathrm{CC}= \\
\mathrm{CH}\end{array}$ & $\begin{array}{l}3-\left(\mathrm{NO}_{2}\right) 4-(\mathrm{Cl})- \\
\mathrm{C}_{6} \mathrm{H}_{3}\end{array}$ & $\mathrm{C}_{2} \mathrm{H}_{5}$ \\
\hline 39 & $4 w^{d}$ & $\mathrm{HC}=\mathrm{CH}$ & $\begin{array}{l}3-\left(\mathrm{NO}_{2}\right) 4-(\mathrm{Br})- \\
\mathrm{C}_{6} \mathrm{H}_{3}\end{array}$ & $\mathrm{C}_{2} \mathrm{H}_{5}$ \\
\hline
\end{tabular}

${ }^{a}$ Taken from Ref. [13].

b Taken from Ref. [26].

c Taken from Ref. [14].

d Taken from Ref. [18].

e Taken from Ref. [19].

${ }^{f}$ Taken from Ref. [16].

g Taken from Ref. [20].

h Taken from Ref. [21].

i Taken from Ref. [22].

j Taken from Ref. [23].

k Taken from Ref. [24].

${ }^{1}$ Taken from Ref. [17]. m Taken from Ref. [25].

U-373 MG astrocytoma cells were exposed to ischemia-like condition (oxygen glucose deprivation and reperfusion, OGD/R) and human SH SY5Y neuroblastoma cells were treated with glutamate in order to resemble two different experimental models of excitotoxicity-mediated injury. Neuroprotection was assessed by using Alamar blue assay that provides an indication of the metabolic activity of cells. Finally, since brain slices are very useful for examining pathophysiology of brain diseases in a tissue context, the effects of the most interesting nineteen derivatives $(5-7,9,12,14,16,18,22,24,27,28,30,33$, 35-39) on rat cortical brain slices subjected to ischemia-like conditions (oxygen-glucose deprivation and reperfusion, OGD/R) were also investigated. Brain slices, in fact, maintain many aspects of in vivo biology, including functional local synaptic circuitry with preserved brain architecture, while allowing good experimental access and precise control of the extracellular environment, providing surrogate therapeutic screening systems without the recourse to whole animal studies. In this experimental model, neuroprotection afforded by the drugs was assessed by measuring lactate dehydrogenase (LDH) leakage into the incubation medium. LDH, in fact, is an intracellular enzyme which moves from the cytosol to the extracellular compartment subsequent to membrane collapse. Its increase in slices incubation medium is generally taken as an index of tissue injury. The activity of nifedipine and the derivatives which exhibited neuroprotection as the parent drug were further investigated for their ability to reduce tissue edema. Because of the dominant effect of hypoxia on cells, in fact, cerebral ischemia leads primarily to cytotoxic edema, a major factor of morbidity and mortality in stroke [32,33]. Consequently, a reduction in tissue water content after the injury can be taken as a further index of neuroprotection, especially when considering that new strategies for the prevention and treatment of brain cytotoxic edema are strongly needed.

\subsection{Cardiovascular functional studies}

The peripheral profile on the cardiovascular system of all the new compounds (10-24, 30, 32 and 34-39) was derived on guinea-pig isolated left and right atria to evaluate their inotropic and chronotropic effects, respectively, and on $\mathrm{K}^{+}$-depolarized $(80 \mathrm{mM})$ guinea-pig vascular (aortic strips) smooth muscle to assess calcium antagonist activity. Compounds were checked at increasing concentrations to evaluate the percent decrease of developed tension on isolated left atrium driven at $1 \mathrm{~Hz}$ (negative inotropic activity), the percent decrease in the atrial rate on spontaneously beating right atrium (negative chronotropic activity) and the percent inhibition of calcium-induced contraction on $\mathrm{K}^{+}$-depolarized aortic strips (vascular). Details have been reported on supporting information.

\section{Results}

Calcium blockers-mediated neuroprotection is generally observed at $\mu \mathrm{M}$ concentration $[10,34,35]$ consequently derivatives 5-39 were tested at 1 and $20 \mu \mathrm{M}$ by adding the compounds during the reperfusion phase (U-373 MG and brain slices) or together with glutamate (SH SY5Y). Nifedipine (1 and $20 \mu \mathrm{M})$ was taken as a reference compound, while vehicle-treated cells/slices were used as controls. Data were expressed as percent of recovery from injury, which varies from 0 (no damage recovered) to $100 \%$ (totally recovered damage) and analyzed by one-way ANOVA followed Bonferroni post-test. The neuroprotective activity of all the tested compounds is summarized in Table 2. In U-373 MG cells nifedipine exert significant neuroprotec- 


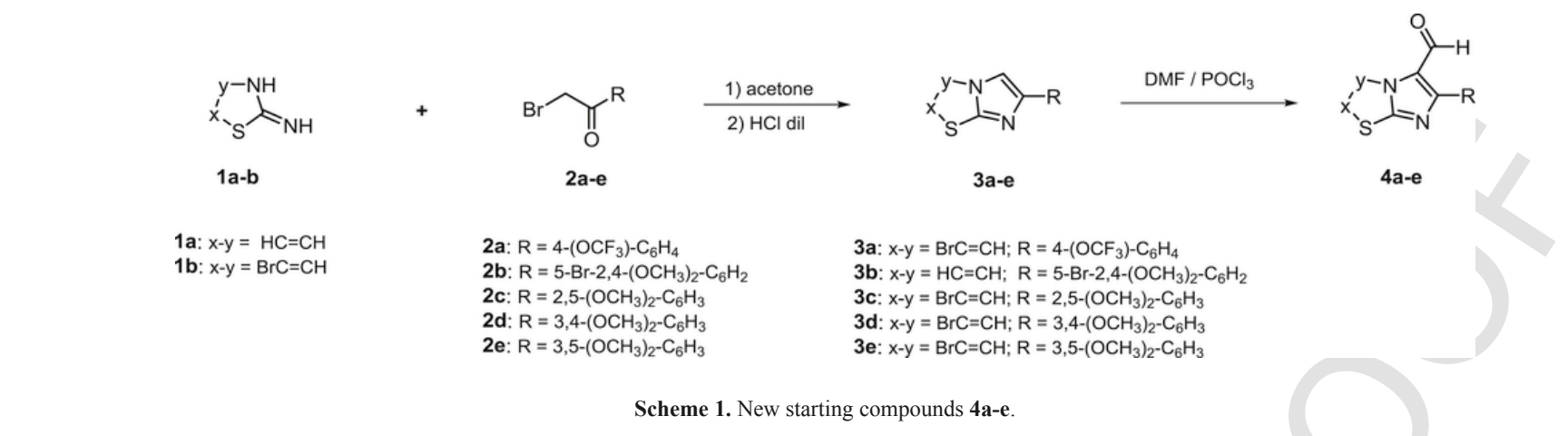

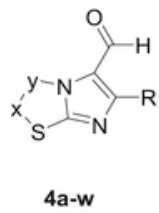
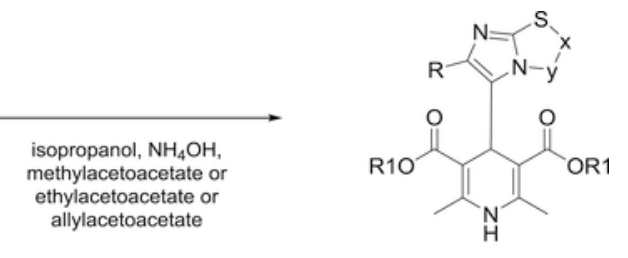

$10-24,30,32,34-39$

Scheme 2. New 1,4-DHPs.

tion since the recovery in cell viability was $34.4 \pm 9.4 \%(P<0.01 v s$ vehicle-treated cells) or $73.7 \pm 14.2(P<0.01 \mathrm{vs}$ vehicle-treated cells $)$ when the drug was present during reperfusion at $1 \mu \mathrm{M}$ or $20 \mu \mathrm{M}$ concentration, respectively. Among all the derivatives, 5, 27, and $\mathbf{2 8}$ were the most effective ones, since cell recovery was higher than that observed for nifedipine treatment at both 1 and $20 \mu \mathrm{M}$ concentrations. Compounds 9, 12, 33 and $\mathbf{3 6}$ possessed lower activity than the parent drug (recovery in cell viability range $40-65 \%$ ), while 10, 11, 14, $18,21,22,24,34,37$ and 39 were poorly neuroprotective (cell recovery $23-37 \%)$. Finally, the remaining compounds were mostly - (13, 23 and 38) or totally-inactive $(6-8,15-17,20,21,25,26,29,30-32$ and 34). In human SH SY5Y neuroblastoma cells treated with glutamate, nifedipine partially $(55.0 \pm 12.1, P<0.001 \mathrm{vs}$ vehicle-treated cells) or fully $(101.6 \pm 4.7, P<0.01 v s$ vehicle-treated cells) recovered glutamate-induced injury at $1 \mu \mathrm{M}$ or $20 \mu \mathrm{M}$ concentration, respectively. Also in this cell line, the most interesting and active compounds resulted to be $\mathbf{5 , 2 7}$ and $\mathbf{2 8}$ which caused neuroprotection in a nifedipine-like fashion. Interestingly, 7, which was inactive in U-373 MG cells, caused huge effects in terms of neuroprotection in SH SY5Y cells. Compounds 11, 12, 16, 18, 22, 30, 33, 35 and 39 exhibited an intermediate activity (cell recovery range $50-67 \%$ ), while $\mathbf{6 , 8 - 1 0}, \mathbf{1 3}$, $14,17,19,20,23,24,29,31,36$ and 37 were poorly active, being cell recovery at the highest concentration of $20 \mu \mathrm{M}$ much lower than that attained after nifedipine treatment. The remaining compounds $(\mathbf{1 5}, \mathbf{2 1}$, 25, 26, 32, 34 and 38) were inactive.

In light of these results, the most active compounds $(\mathbf{5}, 27$ and 28) as well as those that in at least one assay resulted to be more-, equally- or slightly less-active than nifedipine $(6,7,9,12,14,16,18$, 22, 24, 30, 33, 35-39) were further investigated by using a more integrated experimental model. Brain slices, which maintain the exact cellular architecture of an intact brain, can be used for a more appropriate and accurate extrapolation of the findings in terms of neuroprotection. Since excitotoxicity is a key mediator of central neurons loss which occurs in many neurodegenerative diseases as well as during hypoxic-ischemic insults, rat brain slices were exposed to excitotoxic-mediated injury (OGD/R). LDH release from the tissue to the medium was taken to assess neuroprotection and $\mathbf{3 8}$ used as negative control. Compounds were tested at $20 \mu \mathrm{M}$ final concentration and added to the medium during the reperfusion phase, which follows OGD.

Results demonstrated that all the compounds reduced the release of LDH caused by the injury, pointing in this way to their neuroprotective activity (see Table 3 ). In particular, 6 and 7 were the most interesting compound as LDH efflux into the medium was lower than that of control slices. 5, 9, 12, 27, 28 and 33 were effective in a nifedipine-like fashion as the recovery in LDH release ranged between 90 and $70 \%$. The other derivatives, however, proved to be less effective than nifedipine while 18, 35, 38 and 39 (negative control) were ineffective. Cerebral edema is a severe clinical complication in many types of brain insults and it is characterized by the pathological swelling of brain tissue due to the increase of brain water content [36]. Without medical intervention, an increase in intracranial pressure, accompanied by decreased blood flow and tissue ischemia arise within few hours and this is correlated with poor patient outcomes and a greater incidence of mortality [32,33]. Thus a reduction in tissue water content after the injury is of considerable interest to preserve brain tissue. In view of this, the effectiveness in restoring tissue water gain of the derivatives $5-7,9,12,27,28$, and 33 that emerged by their activities in preliminary essays was further investigated. The results showed that nifedipine and all the other derivatives fully reverted tissue water gain induced by ischemia-like conditions, while the negative control 38 was ineffective also in this essay. Some compounds $(\mathbf{6}, 22,27$ and $33)$ proved to be better than nifedipine in restoring tissue water gain induced by ischemia conditions (Table 3, Fig. 2).

Physicochemical and pharmacokinetic properties of 5, 6, 7, 27 and $\mathbf{2 8}$, as well as nifedipine (herein used as reference drug), were calculated and compared as a coarse assessment of the drug-like character of our 1,4-DHPs. To this end, we employed the Qikprop program (Schrödinger. LLC New York). The results are summarized in Table 4.

\section{Discussion}

L-type $\mathrm{Ca}^{2+}$-channels are implicated in many neurological human diseases [37]. Consequently, developing novel and selective blocking agents for neuronal L-type $\mathrm{Ca}^{2+}$ channel might be important for the treatment of neurodegenerative diseases $[6,9]$ not only in view of the possibility to short-circuit the entire downstream pathways of excitotoxicity, but also to overcome other hurdles in the clinical treatment of these pathologies. 1,4-DHPs such as isradipine, in fact, possesses multiple beneficial effects besides their primary L-calcium channel blocking ability [38]. A rigorous phase III clinical trial is ongoing to provide proof on the effectiveness of isradipine for treatment in Parkinson disease [39]. In the present study, we investigated the neuroprotective effect and cardiovascular activity of nifedipine and other thirty-five compounds with a 1,4-DHP scaffold bearing in $\mathrm{C} 4$ a dif- 
Table 2

Recovery in cell viability afforded by nifedipine and 5-39 derivatives in human - astrocytoma and -neuroblastoma cells subjected to excitotoxic-like injury.

\begin{tabular}{|c|c|c|c|c|}
\hline \multirow[t]{2}{*}{ compd } & \multicolumn{2}{|c|}{ Human Astrocytoma (U-373 MG) cell recovery after OGD/R (\%) } & \multicolumn{2}{|c|}{ Human Neuroblastoma (SH SY5Y) cell recovery after GLU (\%) ${ }^{\mathrm{a}}$} \\
\hline & $1 \mu \mathrm{M}$ & $20 \mu \mathrm{M}$ & $1 \mu \mathrm{M}$ & $20 \mu \mathrm{M}$ \\
\hline Nif & $34.4 \pm 9.4 * *$ & $73.7 \pm 14.2 * * *$ & $55.0 \pm 12.1 * * *$ & $101.6 \pm 4.7^{* * *}$ \\
\hline 5 & $73.0 \pm 6.5^{* * *} \S \S$ & $86.7 \pm 4.2^{* * *}$ & $44.1 \pm 4.9 * * *$ & $84.5 \pm 9.1 * * *$ \\
\hline 6 & \# & \# & $35.4 \pm 7.0 * * *$ & $44.1 \pm 3.8^{* * *}$ \\
\hline 7 & \# & \# & $85.1 \pm 9.4 * * * \S$ & $130.0 \pm 7.3 * * * \S \S$ \\
\hline 8 & $\#$ & \# & $17.5 \pm 4.7^{*}$ & $36.6 \pm 6.4 * * *$ \\
\hline 9 & $52.3 \pm 6.5^{* * *}$ & $54.2 \pm 6.2 * * *$ & $37.4 \pm 3.2 * * *$ & $37.7 \pm 5.4^{* * *}$ \\
\hline 10 & $14.2 \pm 9.0$ & $23.8 \pm 8.9$ & \# & $49.8 \pm 10.2 * * *$ \\
\hline 11 & $\#$ & $36.8 \pm 9.6^{* * *}$ & $53.2 \pm 2.3^{* * *}$ & $62.2 \pm 6.8^{* * *}$ \\
\hline 12 & $36.6 \pm 8.9^{* *}$ & $43.6 \pm 10.9^{* *}$ & $42.6 \pm 4.3^{* * *}$ & $59.3 \pm 7.1 * * *$ \\
\hline 13 & $9.1 \pm 6.3$ & $13.2 \pm 5.8$ & $28.9 \pm 10.3^{*}$ & $43.1 \pm 8.6^{* * *}$ \\
\hline 14 & $32.6 \pm 6.0^{* *}$ & $33.7 \pm 7.6^{* *}$ & $44.9 \pm 7.3 * * *$ & $47.5 \pm 6.6^{* * *}$ \\
\hline 15 & \# & \# & \# & \# \\
\hline 16 & \# & \# & $37.4 \pm 4.7 * *$ & $50.7 \pm 6.0^{* * *}$ \\
\hline 17 & \# & \# & $19.5 \pm 6.1^{*}$ & $27.7 \pm 8.5^{*}$ \\
\hline 18 & $7.4 \pm 15.6$ & $30.6 \pm 6.0^{*}$ & \# & $54.7 \pm 8.4^{* * *}$ \\
\hline 19 & $\#$ & $\#$ & $6.8 \pm 2.3$ & $44.4 \pm 8.7 * *$ \\
\hline 20 & \# & $\#$ & $25.1 \pm 10.2 *$ & $47.1 \pm 5.9^{* *}$ \\
\hline 21 & $10.3 \pm 6.9$ & $26.1 \pm 12.2 *$ & \# & \# \\
\hline 22 & $22.2 \pm 7.1$ & $28.5 \pm 5.0^{*}$ & $28.8 \pm 10.1^{*}$ & $51.1 \pm 7.2 * * *$ \\
\hline 23 & $16.5 \pm 6.7$ & $15.4 \pm 6.7$ & $40.8 \pm 8.7 * * *$ & $40.7 \pm 9.8^{* * *}$ \\
\hline 24 & $21.2 \pm 7.4$ & $26.7 \pm 10.1^{*}$ & $14.7 \pm 6.8^{*}$ & $41.6 \pm 7.0^{* * *}$ \\
\hline 25 & \# & $\#$ & $\#$ & $\#$ \\
\hline 26 & \# & \# & \# & \# \\
\hline 27 & $82.9 \pm 4.7 * * * \S \S \S$ & $96.7 \pm 5.7 * * *$ & $51.9 \pm 10.0 * * *$ & $99.0 \pm 10.2 * * *$ \\
\hline 28 & $78.8 \pm 5.7 * * * \S \S$ & $99.6 \pm 2.5^{* * *}$ & $42.0 \pm 7.8 * * *$ & $108.4 \pm 4.5^{* * *}$ \\
\hline 29 & $\#$ & $\#$ & $13.1 \pm 3.6$ & $36.8 \pm 5.3^{*}$ \\
\hline 30 & \# & $\#$ & $40.6 \pm 4.3^{* * *}$ & $52.3 \pm 5.6^{* * *}$ \\
\hline 31 & \# & \# & $31.5 \pm 7.9^{* *}$ & $46.3 \pm 6.2^{* * *}$ \\
\hline 32 & \# & \# & \# & \# \\
\hline 33 & $36.6 \pm 8.9^{* * *}$ & $65.7 \pm 2.8^{* * *}$ & $42.8 \pm 4.3 * * *$ & $67.4 \pm 9.1 * * *$ \\
\hline 34 & $\#$ & $\#$ & $\#$ & $\#$ \\
\hline 35 & $\#$ & $29.32 \pm 14.7$ & \# & $57.6 \pm 9.8^{* * *}$ \\
\hline 36 & $9.0 \pm 7.8$ & $55.1 \pm 13.4^{* * *}$ & $18.2 \pm 4.8^{*}$ & $33.4 \pm 6.2 * * *$ \\
\hline 37 & $\#$ & $29.6 \pm 3.3$ & $17.4 \pm 3.5^{*}$ & $42.4 \pm 8.0 * * *$ \\
\hline 38 & \# & \# & \# & \# \\
\hline 39 & \# & $32.4 \pm 10.4^{* *}$ & \# & $59.2 \pm 6.4^{* * *}$ \\
\hline
\end{tabular}

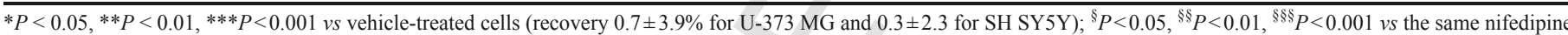
concentration (one-way ANOVA and Bonferroni post-test). \# Inactive up to the concentration indicated above. Recovery in cell viability $<5.0 \%$.

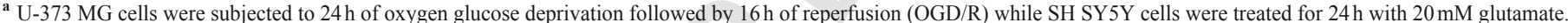
The compounds were added at $1 \mu \mathrm{M}$ or $20 \mu \mathrm{M}$ final concentration in the reperfusion phase (U-373 MG) or with glutamate (SH SY5Y). The recovery values varies from 0 (no damage recovered) to $100 \%$ (totally recovered damage). Data are presented as mean \pm S.E. of at least three independent experiments conducted in sixtuplicate.

ferently substituted imidazo[2,1-b]thiazole system. The mechanism(s) underlying neuroprotection elicited by L-type CCBs, however, is still debated and seems to depend on their ability to reduce calcium entry into the cells as well as on their antioxidant [40] and by anti-inflammatory properties [35]. Since both these mechanisms may influence the progression of cell death after the injury, appropriate pharmacological models to enable measurements of the neuroprotective effects are required. In the present study cellular models (U-373 MG and SH SY5Y as human astrocytes and neuronal cells, respectively) were used and these were integrated by a brain tissue context-model (rat brain slices), which allows neuroprotection assessment of novel compounds without complication from brain penetration or metabolic stability. In the latter model, all derivatives were added after the injury since from a clinical point of view this is more relevant than the treatment performed before the damage, being neurodegeneration almost unpredictable. Finally, since the presence of L-type calcium channels in human glial cells is still elusive, data from U-373 MG cells models could also help highlighting calcium channel-independent neuroprotective effects exerted by the novel compounds here investigated. Results demonstrated that the most interesting compounds were 5, 27 and $\mathbf{2 8}$ which were equally or more neuroprotec- tive than nifedipine and, at the same time, less active at the cardiovascular level when tested at $20 \mu \mathrm{M}$ concentration (Fig. 3). Interestingly, some compounds were totally ineffective in U-373 MG cells, but exerted significant $(7)$ or mild $(\mathbf{6}, \mathbf{1 6}, \mathbf{3 0}, \mathbf{3 1})$ neuroprotection in SH-SY5Y - and brain slices-models. This can be explained by considering that L-type channel blockers-mediated neuroprotection is very complex mechanism, which results from the interaction among multiple signaling pathways. In neurons, it is generally ascribable to calcium channel-dependent events while in microglia is linked to calcium channel-independent mechanisms. Nimodipine, for example, modulates the pro-inflammatory activity, decreases the levels of NO, iNOS and ROS [41], activates the Akt/CREB signaling pathway and inhibits autophagy [42] while lercandipine possesses antioxidant, antiinflamatory, antiapoptotic along with calcium channel blocking activity [43]. Thus, the present results suggest that U-373 MG cells do not seem to possess directed targets for $\mathbf{6 , 7 , 1 6 , 3 0}$ and 31 or it can be speculated that in the same cells these derivatives simultaneously activate neuroprotective/neurodamaging pathways with net final effect of apparent inefficacy. Moreover, derivatives 6, 7, 9, 12 and 33 were less active than nifedipine in cell culture experiments, while in brain slices their effects were comparable or higher than nifedipine itself 
Table 3

Neuroprotection afforded by nifedipine and 5-7,9,12,14,16,18,22,24,27,28,30,33,35-39 derivatives in rat brain slices subjected to ischemia and reperfusion-like injury.

\begin{tabular}{lll}
\hline Compd. & $\begin{array}{l}\text { Recovery of LDH release after } \\
\text { OGD } / \mathrm{R}(\%)^{\mathrm{a}}\end{array}$ & $\begin{array}{l}\text { Recovery of EDEMA } \\
\text { formation }(\%)^{\mathrm{b}}\end{array}$ \\
\hline Nif & $72.3 \pm 3.3^{* *}$ & $95.7 \pm 12.7^{* * *}$ \\
$\mathbf{5}$ & $79.2 \pm 5.1^{* *}$ & $105.4 \pm 8.2^{* *}$ \\
$\mathbf{6}$ & $100.3 \pm 1.8^{* * *} \S$ & $63.7 \pm 6.3^{*}$ \\
$\mathbf{7}$ & $100.65 \pm 5.4^{* * *}$ & $82.5 \pm 10.4^{* * *}$ \\
$\mathbf{9}$ & $93.8 \pm 4.9^{* * *}$ & $93.8 \pm 4.9^{* * *}$ \\
$\mathbf{1 2}$ & $72.4 \pm 5.7^{* *}$ & $89.4 \pm 3.6^{* *}$ \\
$\mathbf{1 4}$ & $61.9 \pm 19.14$ & $\#$ \\
$\mathbf{1 6}$ & $20.5 \pm 8.3$ & $80.5 \pm 6.8^{* *}$ \\
$\mathbf{1 8}$ & $\#$ & $\#$ \\
$\mathbf{2 2}$ & $23.3 \pm 16.7$ & $76.4 \pm 13.7^{* *}$ \\
$\mathbf{2 4}$ & $18.0 \pm 11.5$ & $\#$ \\
$\mathbf{2 7}$ & $83.9 \pm 4.2^{* * *}$ & $77.6 \pm 4.8^{* * *}$ \\
$\mathbf{2 8}$ & $81.3 \pm 4.0^{* *}$ & $91.8 \pm 5.3^{* * *}$ \\
$\mathbf{3 0}$ & $51.2 \pm 10.8$ & $82.0 \pm 13.3^{* *}$ \\
$\mathbf{3 3}$ & $87.0 \pm 6.5^{* *}$ & $75.8 \pm 1.5^{* * *}$ \\
$\mathbf{3 5}$ & $\#$ & $\#$ \\
$\mathbf{3 6}$ & $57.8 \pm 20.1$ & $89.1 \pm 17.7^{* *}$ \\
$\mathbf{3 7}$ & $14.5 \pm 4.6$ & $\#$ \\
$\mathbf{3 8}$ & $\#$ & $\#$ \\
$\mathbf{3 9}$ & $\#$ & $\#$ \\
\hline
\end{tabular}

${ }^{*} P<0.05, * * P<0.01, * * * P<0.001$ vs vehicle-treated slices. ${ }^{\S} P<0.01$ vs nifedipine (one-way ANOVA and Bonferroni post-test). \# Inactive: recovery in LDH release $<5.0 \%$.

${ }^{a}$ Rat brain slices were subjected to oxygen glucose deprivation ( $\left.30 \mathrm{~min}\right)$ and reperfusion $(90 \mathrm{~min})(\mathrm{OGD} / \mathrm{R})$ and compounds were added at $20 \mu \mathrm{M}$ final concentration in the reperfusion phase. The recovery values vary from 0 (no damage recovered) to $100 \%$ (totally recovered damage).

${ }^{b}$ Data are presented as mean \pm S.E. of at least four independent experiments.

(see Tables 2 and 3, Fig. 3). Thus we can hypothesize that different affinities of these 1,4-DHP towards some L-type $\mathrm{Ca}^{2+}$ channel subunit(s), or other different cellular targets, which are expressed in intact tissue and not in cells, may be at the basis of the differences in their efficacy. Functional selectivity on cardiovascular isolated tissues has been done for all new compounds 10-24, 30, 32, 34-39. To further elucidate structure-activity relationships, data about the compounds (5-9, 25-29, 31 and 33of the library previously published $[13,14,26]$, were included in Table $4 \mathrm{~S}$. The evaluation of compounds cardiovascular parameters (inotropy, chronotropy and calcium-mediated spasmolytic effect) have shown that the most interesting compounds emerging by preliminary studies 5-7, 9, 12, 27, 28 and 33 also have a peculiar profile at the peripheral level. Compounds are generally negative inotropic $(\mathbf{9}, 27)$ or have both effects $(5,7,12,28,33)$. Compound 27 showed selectivity toward atrial LTCC but has also an affinity for Cav1.3 of cortex while 5 bind Cav1.2/Cav1.3 of cortex but does not bind in atrium and ventricle cells [14]. In terms of potency on cardiovascular parameters, even if compounds are not generally more powerful than nifedipine, they are much more selective for one of the parameters considered. In particular, compound 6 has an intrinsic activity of less than $50 \%$ on all the parameters considered and it is completely devoid of cardiac effects. Compounds 5, 27 and $\mathbf{2 8}$ are devoid of vascular effects. The evaluation of neuroprotection and cardiovascular activities by in vitro some essays and in isolated tissues for identification of the most promising molecules of the small library of the imidazo[2,1-b]thiazole-1,4-DHP allows us to define some emerging relationships. Imidazo[2,1-b]thiazole substituents at $\mathrm{C} 2$ and $\mathrm{C} 6$ are able to change not only the cardiovascular parameters $[13,14]$ but also the neuroprotection activity. This effect emerges considering the most interesting compounds of the series for neuroprotective action $(\mathbf{5}-\mathbf{7}, \mathbf{9}, \mathbf{1 2}, \mathbf{2 7}, \mathbf{2 8}, \mathbf{3 3})$. They seem to have little affinity for voltage-dependent $\mathrm{Ca}^{2+}$ channels of the cardiovascular system and of the smooth muscle of nonvascular tissues to reduce side effects and to enhance neural affinity. The 6-position of the imidazo[2,1-b]thiazole greatly influences the activity: an aromatic ring $(7,9,12,27$, 28 and 33 ) is allowed but nature and position of its substituents in a critical determinant $(\mathbf{7} v s \mathbf{2 9} \mathbf{9}$ vs $\mathbf{8} ; \mathbf{1 2}$ vs 11; 27 vs 25; 28 vs $\mathbf{3 6}$ and 37; 33 vs 31). As confirmation of this we can consider derivatives 5-8. Here, a trifluoromethyl substituent positively influences the activity when directly bound to the heterocyclic framework in position 6 (5 and 6), but has no effect when present on the phenyl ring (8). On the contrary the effect on the activity is very different when it is present an oxygen atom that alters the influence of the trifluoromethyl group on the electronic ring distribution (7). The 2-position of the imidazo[2,1-b]thiazole does not allow many variations. The presence of a hydrogen is generally favored $(5,9,12,27$ and 33) and its substitution conditions the effect on the neuroprotection sensitively in a positively $\left(-\mathrm{H} v s-\mathrm{CH}_{3}\right.$ or $-\mathrm{Cl}$ : 5 vs $\mathbf{6 , 3 3}$ vs 28) or negatively $\left(-\mathrm{H} v s-\mathrm{Br}\right.$ or $-\mathrm{CH}_{3}$ or $-\mathrm{Cl},-\mathrm{Cl}$ vs $-\mathrm{Br}: 9$ vs 10,

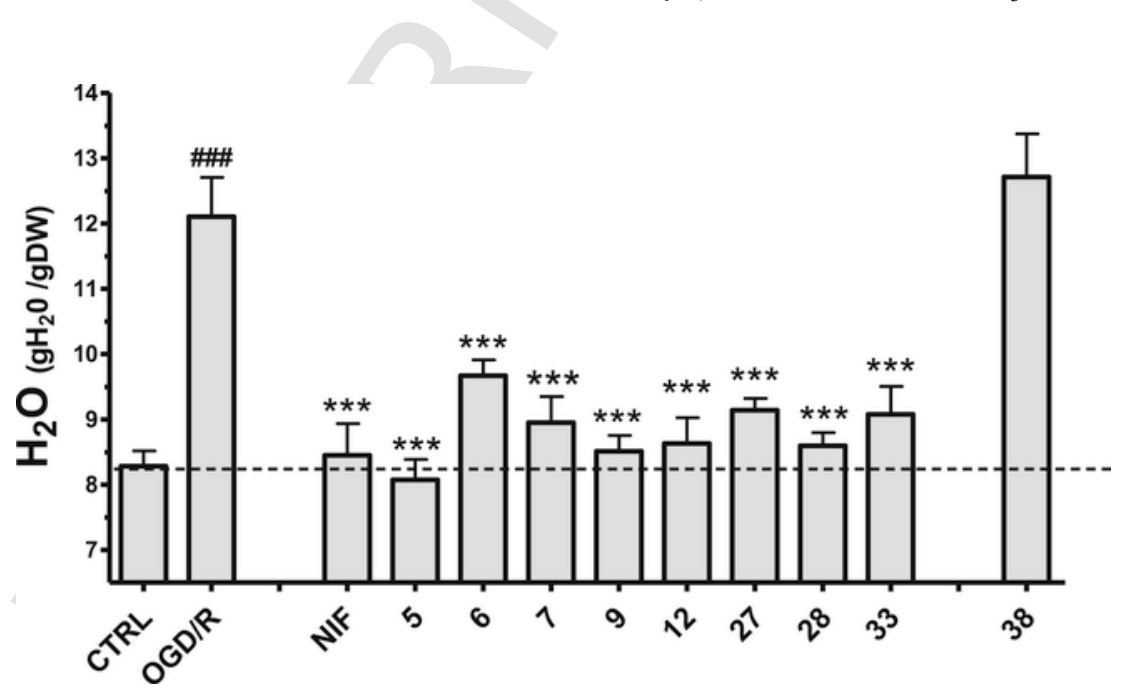

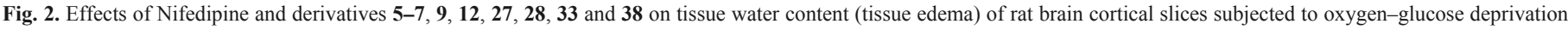

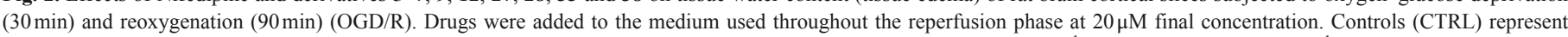

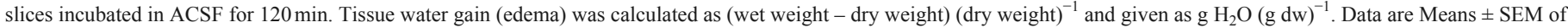
at least 4 different and independent experiments. ${ }^{*} P<0.01, * * * P<0.001$ vs OG/R; \#\#\#P<0.01 vs CTRL (one-way ANOVA and Bonferroni post-test). 
Table 4

Calculated physicochemical and pharmacokinetic properties of compounds 5, 6, 7, 27 and 28 .

\begin{tabular}{|c|c|c|c|c|c|c|c|}
\hline Compound & 5 & 6 & 7 & 27 & 28 & Nif. & Range or recommended values ${ }^{\mathrm{a}}$ \\
\hline \#rotor $^{\mathrm{b}}$ & 2 & 2 & 2 & 4 & 4 & 3 & $0-15$ \\
\hline$\#$ rtvFG $^{\mathrm{c}}$ & 2 & 2 & 2 & 2 & 2 & 2 & $0-2$ \\
\hline $\mathbf{C N S}^{\mathrm{d}}$ & 0 & 0 & 0 & 0 & 0 & 0 & $\begin{array}{l}-2 \text { (inactive) } \\
+2 \text { (active) }\end{array}$ \\
\hline mol_MW & 415.4 & 429.4 & 437.5 & 483.5 & 518.0 & 346.3 & $130.0-725.0$ \\
\hline dipole $^{f}$ & 6.0 & 6.4 & 6.4 & 3.8 & 3.6 & 3.1 & $1.0-12.5$ \\
\hline SASA $^{g}$ & 589.9 & 623.7 & 626.2 & 695.5 & 722.6 & 533.0 & $300.0-1000.0$ \\
\hline donorHB $^{\mathrm{h}}$ & 0 & 0 & 0 & 0 & 0 & 0 & $0.0-6.0$ \\
\hline $\operatorname{accptHB}^{i}$ & 5 & 5 & 5 & 6.5 & 6.5 & 4.5 & $2.0-20.0$ \\
\hline QPlogPo/w & 3.8 & 4.1 & 4.6 & 4.6 & 5.1 & 3.1 & $-2.0-6.5$ \\
\hline$Q P \log S^{k}$ & -5.0 & -5.6 & -5.4 & -5.6 & -6.4 & -3.8 & $-6.5-0.5$ \\
\hline QPPCaco $^{1}$ & 1467.2 & 1467.2 & 1617.8 & 1756.3 & 1756.0 & 978.2 & $\begin{array}{l}<25 \text { poor, } \\
>500 \text { great }\end{array}$ \\
\hline $\mathbf{Q P} \log B B^{\mathrm{m}}$ & 0.0 & -0.1 & -0.1 & -0.3 & -0.1 & -0.5 & $-3.0-1.2$ \\
\hline QPPMDCK $^{\mathrm{n}}$ & 3947.3 & 3593.5 & 1677.9 & 1833.7 & 4462.7 & 483.1 & $\begin{array}{l}<25 \text { poor, } \\
>500 \text { great }\end{array}$ \\
\hline$\#$ metab $^{\circ}$ & 5 & 6 & 6 & 7 & 7 & 6 & $1-8$ \\
\hline $\begin{array}{l}\text { Human Oral } \\
\text { Absorption }^{p}\end{array}$ & 3 & 3 & 3 & 3 & 1 & 3 & $\begin{array}{l}<25 \% \text { poor, } \\
>80 \% \text { high }\end{array}$ \\
\hline
\end{tabular}

${ }^{\text {a }}$ For $95 \%$ of known drugs.

${ }^{\mathbf{b}}$ Number of non-trivial (not CX3), non-hindered (not alkene, amide, small ring) rotatable bonds.

c Number of reactive functional groups.

${ }^{\text {d }}$ Predicted central nervous system activity on a -2 (inactive) to +2 (active) scale.

e Molecular weight of the molecule.

${ }^{f}$ Computed dipole moment of the molecule.

g Total solvent accessible surface area (SASA) in square angstroms using a probe with a $1.4 \AA$ radius.

h Estimated number of hydrogen bonds that would be donated by the solute to water molecules in an aqueous solution.

${ }^{i}$ Estimated number of hydrogen bonds that would be accepted by the solute from water molecules in an aqueous solution.

j Predicted octanol/water partition coefficient.

${ }^{\mathbf{k}}$ Predicted aqueous solubility, $\log \mathrm{S}$. S in mol dm${ }^{-3}$ is the concentration of the solute in a saturated solution that is in equilibrium with the crystalline solid.

${ }^{1}$ Predicted apparent Caco-2 cell permeability in $\mathrm{nm} / \mathrm{sec}$. Caco-2 cells are a model for the gut-blood barrier.

${ }^{m}$ Predicted brain/blood partition coefficient.

${ }^{n}$ Predicted apparent MDCK cell permeability in $\mathrm{nm} / \mathrm{sec}$. MDCK cells are considered to be a good mimic for the blood-brain barrier.

${ }^{0}$ Number of likely metabolic reactions.

p Predicted qualitative human oral absorption.

12 vs 13, 12 vs 14, 28 vs 35, 33 vs 34, 33 vs 35) influences neuroprotective effect. The $-\mathrm{Cl}$ and the $-\mathrm{CH}_{3}$ substituents in position 2 have a detrimental or neutral effect on the neuroprotective activity. Therefore this position is less interesting to be further inspected in future works. Biological results also point out that esterification of the carboxylic functions in positions 3 and 5 of the 1,4-DHP ring with methyl $(5,6,7,9,27$ and 28$)$ or ethyl group positively affects the central effects (12 and 33), but these functions per se are not significant for defining the SARs since the same esters are also present in the less interesting series' derivatives.

Quantitative structure-activity relationship (QSAR) studies on CNS active compounds and their derivatives, together with analyses based on CNS drugs, have suggested the physical and chemical properties that CNS compounds must possess. They are: molecular weight (MW) less than 450, ClogP less than 5, number of H-bond acceptor atoms less than 7, polar surface area (PSA) less than $90 \AA$, number of rotatable bonds $(\mathrm{RB})$ less or equal to 10 . Thus, for CNS penetration, the physical properties, usually, have a smaller range than general. On the basis of these premises, the best performing 1,4-DHPs (5-7, 27 and 28) are predicted to have a fair probability of entering the CNS (Table 4), as all its estimated physicochemical parameters fall in the aforementioned ranges. Moreover, the QPPMDCK parameter estimating the cell permeability in MDCK cells, which are mimics of the blood-brain barrier (BBB), would outline that the selected compounds have a greater brain penetration potential with respect to Nifedipine. However, it has to be pointed out that the present in silico prediction neglects uptake mechanisms such as carrier-mediated uptake, receptor-mediated transport, and active efflux that can greatly affect the BBB crossing of a drug.

\section{Conclusions}

L-Type calcium channels in brain are considered targets for the research of therapies for numerous pathological conditions $[12,44]$. 1,4-DHPs, channel blockers have a long history of safe use as antihypertensive agents. The neuroprotective effects of first and second-generation 1,4-DHPs L-Type calcium channel blockers such as nifedipine, have been extensively investigated and were first suggested to have neuroprotective effects [45]. 1,4-DHP channel blockers are nonselective, blocking both Cav1.2 and Cav1.3 channels. The lack of selectivity has excluded any clinically important application as neuroprotective agents. Nevertheless, the results of our previous studies of 1,4-DHPs derivatives obtained by a ligand-based design approach, has allowed us to further investigate this scaffold to examine any possible neuroprotective effects. Among all the compounds tested, only a small number showed an interesting biological profile. It is evident that for the most interesting compounds, in the experimental models considered, the cardiovascular effects are generally lower with respect to those of nifedipine and above all the maximum efficacy in the cardiovascular effects is reached at lower concentrations than those required to obtain the effects on cells cultures and brain cortical slices (Fig. 3). In particular, compound $\mathbf{6}$ is the one that best fits this 

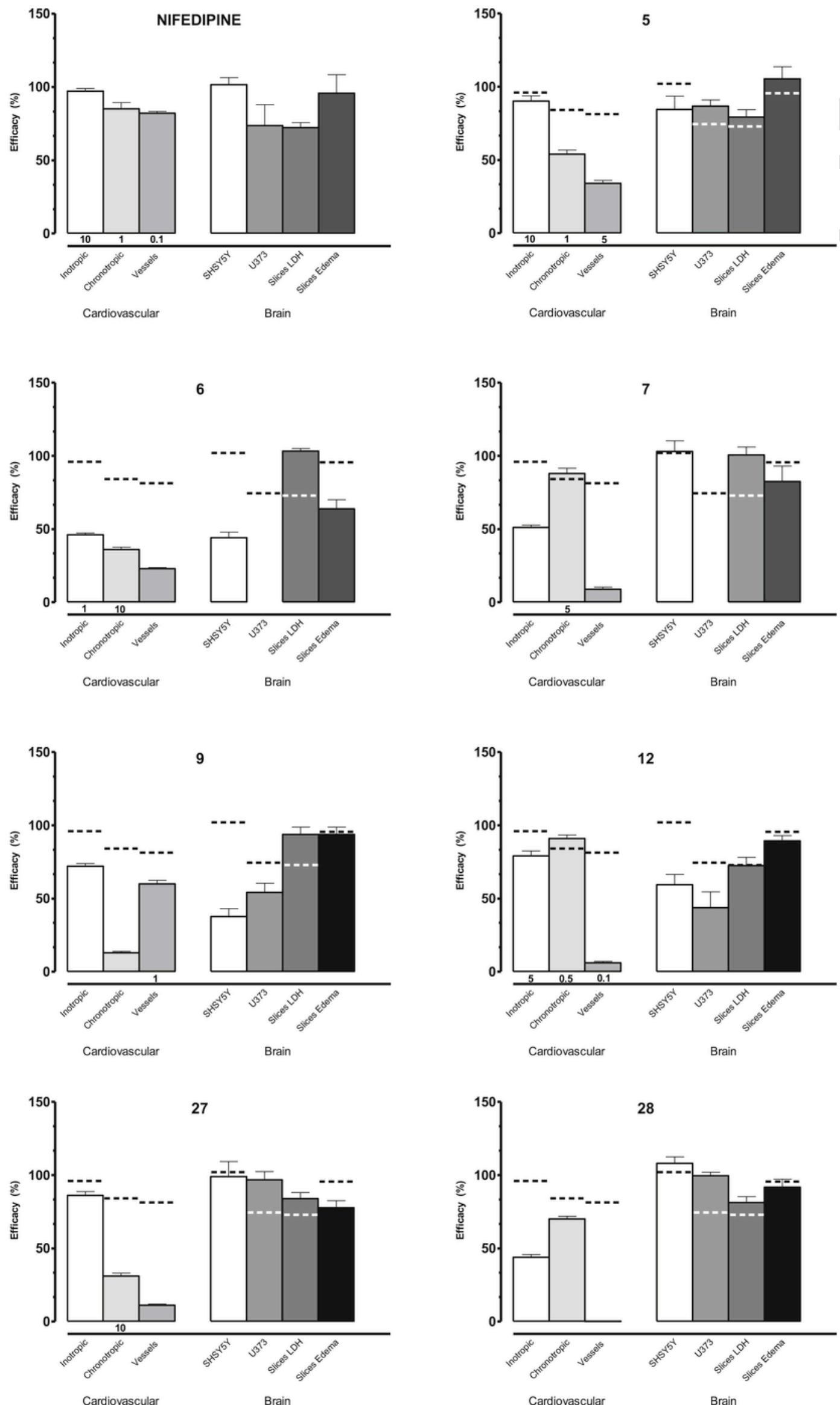
profile. In addition, nifedipine exerts its effects including significant vasodilation through direct action on the calcium channels while compounds that emerged as more interesting in the assessment of neuroprotection did not show a significant vaso-relaxing effect $(\mathbf{5}, \mathbf{6}, \mathbf{7}, \mathbf{2 7}$, 28). It can, therefore, be hypothesized that, in vivo, unlike nifedipine [7], they have their neuroprotection effects independently of vasodilation. In addition, the evaluation of physicochemical and pharmacokinetic properties compared to nifedipine (Table 4), indicates that the appropriately decorated 1,4-DHP scaffold might be used for the modulation of brain calcium channels. Chemical modifications of the initial hits are necessary to further improve the BBB passage and then to verify central action in in vivo experiments. This preliminary study prompts us to future evaluations aimed at identifying new 1,4-DHPs which, when appropriately substituted in position 4 , can have applications as neuroprotective agents for treating neurodegenerative diseases without involving voltage-dependent calcium channels at cardiovascular level.

\section{Experimental section}

\subsection{Chemistry}

All the compounds prepared have a purity of at least $95 \%$ as determined by calculation analysis. The melting points are uncorrected. Analyses $(\mathrm{C}, \mathrm{H}, \mathrm{N})$ were within $\pm 0.4 \%$ of the theoretical values. TLC was performed on Bakerflex plates (Silica gel IB2-F); the eluent was a mixture of petroleum ether $60-80^{\circ} \mathrm{C} /$ acetone in various proportions. Kieselgel 60 (Merck) was used for flash chromatography. The IR spectra were recorded in nujol on a Nicolet Avatar 320 E S.P.; $\nu_{\max }$ is expressed in $\mathrm{cm}^{-1}$. The ${ }^{1} \mathrm{H}$ NMR and ${ }^{13} \mathrm{C}$ NMR spectra were recorded on a Varian Gemini $(400 \mathrm{MHz})$; the chemical shift (referenced to solvent signal) is expressed in $\delta$ (ppm) and $J$ in Hz. Abbreviations: th $=$ thiazole, ar $=$ aromatic, $\mathrm{dhp}=$ dihydropyridine, $\mathrm{py}=$ pyridine, ex $=\mathrm{H}$ linked to $\mathrm{N}$ which exchanged with $\mathrm{D}_{2} \mathrm{O}$. All solvents and reagents, unless otherwise stated, were supplied by Aldrich Chemical Company Ltd. and were used as supplied.

\subsubsection{Imidazo[2,1-b]thiazoles 3a-e}

The 2-aminothiazoles 1a-b (as free base, $30 \mathrm{mmol}$ ) were dissolved in acetone $(80 \mathrm{~mL})$ and treated with the appropriate 2-bromo-1-arylethanones 2 a-e $(30 \mathrm{mmol})$. The reaction mixture was refluxed for $3 \mathrm{~h}$ and after cooling the resulting precipitate was collected, suspended in $100 \mathrm{~mL}$ of $2 \mathrm{~N} \mathrm{HCl}$ and refluxed for $2 \mathrm{~h}$. The warm solution, basified with $20 \% \mathrm{NH}_{4} \mathrm{OH}$, after cooling at room temperature yielded the expected imidazo[2,1-b]thiazoles which were filtered. For $\mathbf{3 d}$ the solid was purified by crystallization using toluene, for $\mathbf{3 c}$ by crystallization in ethanol.

\subsubsection{2-Bromo-6-(4-(trifluoromethoxy)phenyl)imidazo[2,1-} b]thiazole (3a)

$36 \%$ yield, mp $145^{\circ} \mathrm{C}$. IR: $3417,3142,1545,1309,1151 .{ }^{1} \mathrm{H}$ NMR $\left(\mathrm{DMSO}-d_{6}\right): 7.38(2 \mathrm{H}, \mathrm{d}, \mathrm{ar}, \mathrm{J}=8.8), 7.94(2 \mathrm{H}, \mathrm{d}, \mathrm{ar}, \mathrm{J}=8.8), 8.29(1 \mathrm{H}$, $\mathrm{s}, \mathrm{im}), 8.32(1 \mathrm{H}, \mathrm{s}, \mathrm{th}) . \mathrm{MW}=363.1576$. Anal. $\left(\mathrm{C}_{12} \mathrm{H}_{6} \mathrm{BrF}_{3} \mathrm{~N}_{2} \mathrm{OS}\right) \mathrm{C}$, $\mathrm{H}, \mathrm{N}$.
7.1.1.2. 6-(5-Bromo-2,4-dimethoxyphenyl)imidazo[2,1-b]thiazole (3b)

$30 \%$ yield, mp $168^{\circ} \mathrm{C}$. IR: $3111,1604,1536,1208,1030 .{ }^{1} \mathbf{H}$ NMR

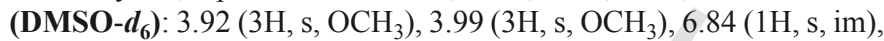
$7.23(1 \mathrm{H}, \mathrm{d}$, th, $\mathrm{J}=4.6), 7.09$ ( $1 \mathrm{H}, \mathrm{d}$, th, $\mathrm{J}=4.6), 8.1(1 \mathrm{H}, \mathrm{s}, \mathrm{ar}), 8.21$ $(1 \mathrm{H}, \mathrm{s}, \mathrm{ar})$.

$$
\mathrm{MW}=339.2128 \text {. Anal. }\left(\mathrm{C}_{13} \mathrm{H}_{11} \mathrm{BrN}_{2} \mathrm{O}_{2} \mathrm{~S}\right) \mathrm{C}, \mathrm{H}, \mathrm{N} \text {. }
$$

\subsubsection{2-Bromo-6-(2,5-dimethoxyphenyl)imidazo[2,1-b]thiazole} (3c)

95\% yield, $\mathrm{mp} 235^{\circ} \mathrm{C}$. IR: $3421,3142,1670,1228,1055 .{ }^{\mathbf{1}} \mathbf{H}$ NMR (DMSO-d d $_{6}: 3.76\left(3 \mathrm{H}, \mathrm{s}, \mathrm{OCH}_{3}\right), 3.89\left(3 \mathrm{H}, \mathrm{s}, \mathrm{OCH}_{3}\right), 6.9(1 \mathrm{H}, \mathrm{dd}$, ar, $\mathrm{J}=8.7, \mathrm{~J}=3.1), 7.07(1 \mathrm{H}, \mathrm{d}$, ar, $\mathrm{J}=8.7), 7.62(1 \mathrm{H}, \mathrm{d}$, ar, $\mathrm{J}=3.1), 8.31$ $(1 \mathrm{H}, \mathrm{s}, \mathrm{im}), 8.37(1 \mathrm{H}, \mathrm{s}, \mathrm{th}) . \mathrm{MW}=339.2128$. Anal. $\left(\mathrm{C}_{13} \mathrm{H}_{11} \mathrm{BrN}_{2} \mathrm{O}_{2} \mathrm{~S}\right)$ $\mathrm{C}, \mathrm{H}, \mathrm{N}$.

\subsubsection{2-Bromo-6-(3,4-dimethoxyphenyl)imidazo[2,1-b]thiazole} (3d)

$20 \%$ yield, mp $114^{\circ} \mathrm{C}$. IR: $1542,1270,1230,1025,856 .{ }^{1} \mathbf{H}$ NMR (DMSO-d d $_{6}: 3.77\left(3 \mathrm{H}, \mathrm{s}, \mathrm{OCH}_{3}\right), 3.81\left(3 \mathrm{H}, \mathrm{s}, \mathrm{OCH}_{3}\right), 6.97(1 \mathrm{H}, \mathrm{d}$, ar, $\mathrm{J}=8.4), 7.36(1 \mathrm{H}, \mathrm{dd}$, ar, $\mathrm{J}=8.4, \mathrm{~J}=2.0), 7.41(1 \mathrm{H}, \mathrm{d}$, ar, $\mathrm{J}=2.0), 8.16$ $(1 \mathrm{H}, \mathrm{s}, \mathrm{im}), 8.29(1 \mathrm{H}, \mathrm{s}, \mathrm{th}) . \mathrm{MW}=339.2128$. Anal. $\left(\mathrm{C}_{13} \mathrm{H}_{11} \mathrm{BrN}_{2} \mathrm{O}_{2} \mathrm{~S}\right)$ $\mathrm{C}, \mathrm{H}, \mathrm{N}$.

\subsubsection{2-Bromo-6-(3,5-dimethoxyphenyl)imidazo[2,1-b]thiazole} (3e)

$45 \%$ yield, $\mathrm{mp} 133^{\circ} \mathrm{C}$. IR: $3124,1599,1189,1156,1066 .{ }^{1} \mathbf{H}$ NMR (DMSO- $\left.\boldsymbol{d}_{6}\right): 3.78\left(6 \mathrm{H}, \mathrm{s}, \mathrm{OCH}_{3}\right), 6.40(1 \mathrm{H}, \mathrm{t}, \mathrm{ar}, \mathrm{J}=2.0), 7.01(2 \mathrm{H}, \mathrm{d}$, ar, $\mathrm{J}=2.0), 8.28(1 \mathrm{H}, \mathrm{s}, \mathrm{im}), 8.31(1 \mathrm{H}, \mathrm{s}, \mathrm{th}) . \mathrm{MW}=339.2128$. Anal. $\left(\mathrm{C}_{13} \mathrm{H}_{11} \mathrm{BrN}_{2} \mathrm{O}_{2} \mathrm{~S}\right) \mathrm{C}, \mathrm{H}, \mathrm{N}$.

\subsubsection{Imidazo[2,1-b]thiazole-5-carboxaldehydes 4a-e}

The Vilsmeier reagent was prepared at $0-5^{\circ} \mathrm{C}$ by dropping $32 \mathrm{mmol}$ of $\mathrm{POCl}_{3}$ into a stirred solution of DMF (39 mmol) in $\mathrm{CHCl}_{3}$ $(5 \mathrm{~mL})$. The appropriate imidazo[2,1-b]thiazoles 3a-e $(12 \mathrm{mmol})$, dissolved in $\mathrm{CHCl}_{3}(60 \mathrm{~mL})$, were added dropwise, under stirring at $0-5{ }^{\circ} \mathrm{C}$, to the Vilsmeier reagent. After $3 \mathrm{~h}$ at room temperature, the reaction mixture was refluxed for $3-14 \mathrm{~h}$ (according to a TLC test acetone/petroleum ether $\left.55-85^{\circ} \mathrm{C}, 1: 9 \mathrm{v} / \mathrm{v}, 2: 8 \mathrm{v} / \mathrm{v}\right)$ and the solvent was evaporated under reduced pressure. The oily residue was poured into ice and the resulting precipitate was collected. For $\mathbf{4 c}$ the crude solid was purified by crystallized from ethanol. For $\mathbf{4 b}$ the derivative was purified by flash chromatography on silica gel (acetone/petroleum ether $40-60^{\circ} \mathrm{C}$ from 1.9 to $4.6 \mathrm{v} / \mathrm{v}$ ).

\subsubsection{2-Bromo-6-(4-(trifluoromethoxy)phenyl)imidazo[2,1- \\ b]thiazole-5-carbaldehyde (4a) \\ $77 \%$ yield, $\mathrm{mp} 135^{\circ} \mathrm{C}$. IR: $3389,1711,1639,1259,1171 .{ }^{\mathbf{1}} \mathbf{H}$ NMR}

(DMSO- $\left.\boldsymbol{d}_{\mathbf{6}}\right): 7.74(2 \mathrm{H}, \mathrm{d}$, ar, $\mathrm{J}=8.5), 8.03(2 \mathrm{H}, \mathrm{d}$, ar, $\mathrm{J}=8.5), 8.66(1 \mathrm{H}$, $\mathrm{s}$, th), $9.91(1 \mathrm{H}, \mathrm{s}, \mathrm{CHO}) . \mathrm{MW}=391.1682$. Anal. $\left(\mathrm{C}_{13} \mathrm{H}_{6} \mathrm{BrF}_{3} \mathrm{~N}_{2} \mathrm{O}_{2} \mathrm{~S}\right)$ $\mathrm{C}, \mathrm{H}, \mathrm{N}$.

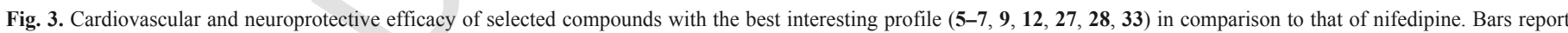

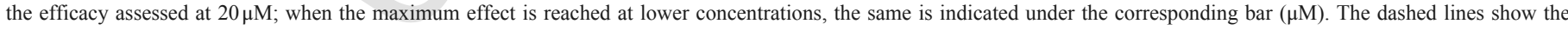
reference values for nifedipine. Data taken from Tables 2 and 3 and S1, are expressed as the mean \pm SEM. 

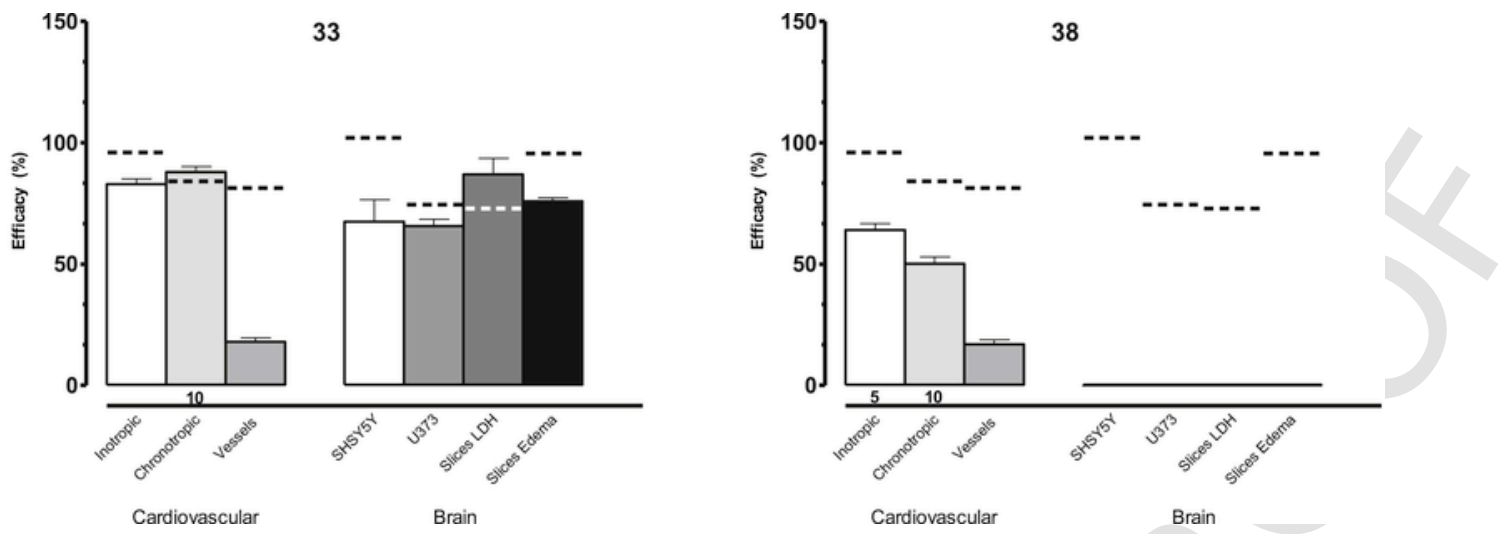

Fig. 3. (Continued)

7.1.2.2. 6-(5-Bromo-2,4-dimethoxyphenyl)imidazo[2,1-b]thiazole-5carbaldehyde (4b)

$37 \%$ yield, mp $217^{\circ} \mathrm{C}$. IR: $3160,3119,1649,1605,1284 .{ }^{1} \mathbf{H}$ NMR (DMSO-d $\left.)_{6}\right): 3.86\left(3 \mathrm{H}, \mathrm{s}, \mathrm{OCH}_{3}\right), 3.97\left(3 \mathrm{H}, \mathrm{s}, \mathrm{OCH}_{3}\right), 6.90(1 \mathrm{H}, \mathrm{s}$, ar), $7.58(1 \mathrm{H}, \mathrm{d}$, th, $\mathrm{J}=6.0), 7.73(1 \mathrm{H}, \mathrm{s}, \mathrm{ar}), 8.35(1 \mathrm{H}, \mathrm{d}$, th, $\mathrm{J}=6.0), 9.66$ $(1 \mathrm{H}, \mathrm{s}, \mathrm{CHO})$. $\mathrm{MW}=367.2234$. Anal. $\left(\mathrm{C}_{14} \mathrm{H}_{11} \mathrm{BrN}_{2} \mathrm{O}_{3} \mathrm{~S}\right) \mathrm{C}, \mathrm{H}, \mathrm{N}$.

\subsubsection{2-Bromo-6-(2,5-dimethoxyphenyl)imidazo[2,1-b]thiazole-5- carbaldehyde (4c)}

$15 \%$ yield, $\mathrm{mp} 150{ }^{\circ} \mathrm{C}$. IR: $3411,1710,1654,1503,1221 .{ }^{1} \mathbf{H}$ NMR (DMSO-d $\left.\boldsymbol{d}_{\mathbf{6}}\right): 3.73\left(3 \mathrm{H}, \mathrm{s}, \mathrm{OCH}_{3}\right), 3.75\left(3 \mathrm{H}, \mathrm{s}, \mathrm{OCH}_{3}\right), 7.05(1 \mathrm{H}$, $\mathrm{dd}$, ar, $\mathrm{J}=9.3, \mathrm{~J}=3.1), 7.13(1 \mathrm{H}, \mathrm{dd}$, ar, $\mathrm{J}=9.3), 7.15(1 \mathrm{H}, \mathrm{d}$, ar, $\mathrm{J}=3.1), 8.60$ (1H, s, th), $9.67(1 \mathrm{H}, \mathrm{s}, \mathrm{CHO})$. $\mathrm{MW}=367.2234$. Anal. $\left(\mathrm{C}_{14} \mathrm{H}_{11} \mathrm{BrN}_{2} \mathrm{O}_{3} \mathrm{~S}\right) \mathrm{C}, \mathrm{H}, \mathrm{N}$.

\subsubsection{2-Bromo-6-(3,4-dimethoxyphenyl)imidazo[2,1-b]thiazole-5- carbaldehyde (4d)}

$67 \%$ yield, mp $174^{\circ} \mathrm{C}$. IR: $3145,1640,1537,1267,1135 .{ }^{1} \mathbf{H}$ NMR (DMSO-d $): 3.83\left(3 \mathrm{H}, \mathrm{s}, \mathrm{OCH}_{3}\right), 3.84\left(3 \mathrm{H}, \mathrm{s}, \mathrm{OCH}_{3}\right), 7.09(1 \mathrm{H}, \mathrm{d}$, ar, $\mathrm{J}=8.4), 7.44(1 \mathrm{H}, \mathrm{dd}$, ar, $\mathrm{J}=8.4, \mathrm{~J}=2.0), 7.47(1 \mathrm{H}, \mathrm{d}$, ar, $\mathrm{J}=2.0)$, $8.63(1 \mathrm{H}, \mathrm{s}, \mathrm{th}), 9.89(1 \mathrm{H}, \mathrm{s}, \mathrm{CHO}) . \mathrm{MW}=367.2234$. Anal. $\left(\mathrm{C}_{14} \mathrm{H}_{11} \mathrm{BrN}_{2} \mathrm{O}_{3} \mathrm{~S}\right) \mathrm{C}, \mathrm{H}, \mathrm{N}$.

\subsubsection{2-Bromo-6-(3,5-dimethoxyphenyl)imidazo[2,1-b]thiazole-5- carbaldehyde (4e)}

$75 \%$ yield, mp $201{ }^{\circ} \mathrm{C}$. IR: $3432,3142,1639,1593,1168 .{ }^{1} \mathbf{H}$ NMR (DMSO-d $)$ ): $3.81\left(6 \mathrm{H}, \mathrm{s}, \mathrm{OCH}_{3}\right), 6.63(1 \mathrm{H}, \mathrm{t}, \mathrm{ar}, \mathrm{J}=2.3), 7.00(1 \mathrm{H}, \mathrm{d}$, ar, $\mathrm{J}=2.3), 8.64(1 \mathrm{H}, \mathrm{s}, \mathrm{th}), 9.90(1 \mathrm{H}, \mathrm{s}, \mathrm{CHO})$. $\mathrm{MW}=367.2234$. Anal. $\left(\mathrm{C}_{14} \mathrm{H}_{11} \mathrm{BrN}_{2} \mathrm{O}_{3} \mathrm{~S}\right) \mathrm{C}, \mathrm{H}, \mathrm{N}$.

\subsubsection{General procedure for the synthesis of the 1,4-} dihydropyridines 10-24, 30, 32, 34-39

Methylacetoacetate or ethylaacetoacetate or allylacetoacetate ( $2 \mathrm{mmol}$ ) and $30 \% \mathrm{NH}_{4} \mathrm{OH}(4 \mathrm{mmol})$ were added to a stirred solution of the appropriate aldehyde 4a-w $(1 \mathrm{mmol})$ dissolved in isopropyl alcohol $(50 \mathrm{~mL})$. The reaction mixture was refluxed for $24-36 \mathrm{~h}$ (according to a TLC test acetone/petroleum ether $55-85^{\circ} \mathrm{C}, 1: 9 \mathrm{v} / \mathrm{v}, 2: 8$ $\mathrm{v} / \mathrm{v})$ and added of methylacetoacetate or ethylaacetoacetate or allylacetoacetate $(4 \mathrm{mmol})$ and $30 \% \mathrm{NH}_{4} \mathrm{OH}(2 \mathrm{mmol})$ every $12 \mathrm{~h}$. After cooling, the mixture was evaporated to dryness under reduced pressure. All the derivatives were purified by flash chromatography on silica gel (acetone/petroleum ether $40-60^{\circ} \mathrm{C}$ from 1.9 to $4.6 \mathrm{v} / \mathrm{v}$; pe- troleum ether $40-60^{\circ} \mathrm{C} /$ diethyl ether:9/1 v/v only for 18) to provide the pure-DHPs as pale yellow syrup. The resulting oily residue was diluted with cold acetone, by addition of a few milliliters of petroleum ether solid products were afforded and collected by filtration for 10-16, 19-24, 30, 32-34 and 38. For 35-36 resulting oils were taken only with acetone to obtain solid products, for $\mathbf{1 8}$ only petroleum ether was added; for 39 a mixture 50/50 of petroleum ether/diethyl ether was used.

\subsubsection{Diethyl 4-\{2-bromo-6-[4-}

(trifluoromethoxy)phenyl]imidazo[2,1-b][1,3]thiazol-5-yl\}-2,6dimethyl-1,4-dihydropyridine-3,5-dicarboxylate (10)

$30 \%$ yield, $\mathrm{mp} 191^{\circ} \mathrm{C}$. IR: $3226,1693,1265,1223,1023 .{ }^{1} \mathbf{H}$ NMR (DMSO- $\left.\boldsymbol{d}_{6}\right): 0.87\left(6 \mathrm{H}, \mathrm{t}, \mathrm{COOCH}_{2} \mathrm{CH}_{3}, \mathrm{~J}=7.1\right), 2.1\left(6 \mathrm{H}, \mathrm{s}, \mathrm{CH}_{3}\right)$, $3.80\left(4 \mathrm{H}, \mathrm{q}, \mathrm{COOCH}_{2} \mathrm{CH}_{3}, \mathrm{~J}=7.1\right), 5.47(1 \mathrm{H}, \mathrm{s}, \mathrm{dhp}), 7.37(2 \mathrm{H}, \mathrm{d}, \mathrm{ar}$, $\mathrm{J}=8.4), 7.73(2 \mathrm{H}, \mathrm{d}$, ar, $\mathrm{J}=8.4), 7.84(1 \mathrm{H}, \mathrm{s}, \mathrm{th}), 8.86(1 \mathrm{H}, \mathrm{s}, \mathrm{NH}$, ex $\left.\mathrm{D}_{2} \mathrm{O}\right) .{ }^{13} \mathbf{C}$ NMR (DMSO- $\boldsymbol{d}_{\mathbf{6}}$ ): 171.83, 172.42, 150.60, 150.47, 146.22, $139.87,135.84,135.00,126.61,126.48,125.56,124.06,104.89$, $103.90, \quad 64.31, \quad 36.83,23.08, \quad 18.94 . \quad \mathrm{MW}=614.4424$. Anal. $\left(\mathrm{C}_{25} \mathrm{H}_{23} \mathrm{BrF}_{3} \mathrm{~N}_{3} \mathrm{O}_{5} \mathrm{~S}\right) \mathrm{C}, \mathrm{H}, \mathrm{N}$.

7.1.3.2. Diethyl 4-[6-(2-fluorophenyl)imidazo[2,1-b][1,3]thiazol-5yl]-2,6-dimethyl-1,4-dihydropyridine-3,5-dicarboxylate (11)

$25 \%$ yield, mp $165^{\circ} \mathrm{C}$. IR: $3182,1697,1273,1202,1096 .{ }^{1} \mathbf{H}$ NMR (DMSO-d d $_{6}: 0.94\left(6 \mathrm{H}, \mathrm{t}, \mathrm{COOCH}_{2} \mathrm{CH}_{3}, \mathrm{~J}=7.0\right), 1.94\left(6 \mathrm{H}, \mathrm{s}, \mathrm{CH}_{3}\right)$, $3.89\left(4 \mathrm{H}, \mathrm{q}, \mathrm{COOCH}_{2} \mathrm{CH}_{3}, \mathrm{~J}=7.0\right), 5.12(1 \mathrm{H}, \mathrm{s}, \mathrm{dhp}), 7.15(3 \mathrm{H}, \mathrm{m}, \mathrm{ar})$, $7.24(1 \mathrm{H}, \mathrm{d}, \mathrm{th}, \mathrm{J}=4.6), 7.37(1 \mathrm{H}, \mathrm{m}, \mathrm{ar}), 7.86(1 \mathrm{H}, \mathrm{d}, \mathrm{th}, \mathrm{J}=4.6), 8.14$ $\left(1 \mathrm{H}, \mathrm{s}, \mathrm{NH}\right.$, ex $\left.\mathrm{D}_{2} \mathrm{O}\right) .{ }^{13} \mathbf{C}$ NMR (DMSO-d $)$ ): 166.69, 145.26, 144.93, $138.28,132.51,131.50,129.83,129.76,123.36,119.87,115.03$, $114.81,111.44,98.77,58.81,30.84,17.75,13.97$

$$
\mathrm{MW}=469.5390 \text {. Anal. }\left(\mathrm{C}_{24} \mathrm{H}_{24} \mathrm{FN}_{3} \mathrm{O}_{4} \mathrm{~S}\right) \mathrm{C}, \mathrm{H}, \mathrm{N} \text {. }
$$

7.1.3.3. Diethyl 4-[6-(4-fluorophenyl)imidazo[2,1-b][1,3]thiazol-5yl]-2,6-dimethyl-1,4-dihydropyridine-3,5-dicarboxylate (12)

$32 \%$ yield, $\mathrm{mp} 173^{\circ} \mathrm{C}$. IR: $3179,1700,1210,1113,722 .{ }^{1} \mathbf{H}$ NMR (DMSO-d $\left.)_{6}\right): 0.86\left(6 \mathrm{H}, \mathrm{t}, \mathrm{COOCH}_{2} \mathrm{CH}_{3}, \mathrm{~J}=7.0\right), 2.13\left(6 \mathrm{H}, \mathrm{s}, \mathrm{CH}_{3}\right)$, $3.76\left(4 \mathrm{H}, \mathrm{q}, \mathrm{COOCH}_{2} \mathrm{CH}_{3}, \mathrm{~J}=7.0\right), 5.53(1 \mathrm{H}, \mathrm{s}, \mathrm{dhp}), 7.21(2 \mathrm{H}$, $\mathrm{t}$, ar-2,6, J=8.8), $7.27(1 \mathrm{H}, \mathrm{d}, \mathrm{th}, \mathrm{J}=4.7), 7.46(1 \mathrm{H}, \mathrm{d}, \mathrm{th}, \mathrm{J}=4.5)$, $7.74(2 \mathrm{H}, \mathrm{dd}$, ar- $3,5, \mathrm{~J}=8.8), 8.82\left(1 \mathrm{H}, \mathrm{s}, \mathrm{NH}\right.$, ex $\left.\mathrm{D}_{2} \mathrm{O}\right) .{ }^{13} \mathbf{C}$ NMR (DMSO-d ): $^{2}$ 166.78, 160.01, 146.56, 145.07, 141.96, 132.33, 132.30, $130.06,129.98,128.88,119.40,114.52,114.31,112.45,98.70,59.03$, 31.43, 17.92, 13.86. $\mathrm{MW}=469.5390$. Anal. $\left(\mathrm{C}_{24} \mathrm{H}_{24} \mathrm{FN}_{3} \mathrm{O}_{4} \mathrm{~S}\right) \mathrm{C}, \mathrm{H}, \mathrm{N}$. 
7.1.3.4. Diethyl 4-[6-(4-fluorophenyl)-2-methylimidazo[2,1-

b][1,3]thiazol-5-yl]-2,6-dimethyl-1,4-dihydropyridine-3,5-

dicarboxylate (13)

$25 \%$ yield, $\mathrm{mp} 225^{\circ} \mathrm{C}$. IR: $3097,1694,1207,1113,858 .{ }^{1} \mathbf{H}$ NMR (DMSO-d d $\left._{6}\right): 0.89\left(6 \mathrm{H}, \mathrm{t}, \mathrm{COOCH}_{2} \mathrm{CH}_{3}, \mathrm{~J}=7.0\right), 2.12\left(6 \mathrm{H}, \mathrm{s}, \mathrm{CH}_{3}\right)$, $2.42\left(3 \mathrm{H}, \mathrm{s}, \mathrm{CH}_{3}\right), 3.80\left(4 \mathrm{H}, \mathrm{q}, \mathrm{COOCH}_{2} \mathrm{CH}_{3}, \mathrm{~J}=7.0\right), 5.47(1 \mathrm{H}, \mathrm{s}$, dhp), $7.19(2 \mathrm{H}, \mathrm{t}, \mathrm{ar}-2,6, \mathrm{~J}=8.5), 7.24(1 \mathrm{H}, \mathrm{s}, \mathrm{th}), 7.70(2 \mathrm{H}, \mathrm{dd}, \mathrm{ar}-3,5$, $\mathrm{J}=8.5$ ), $8.79\left(1 \mathrm{H}, \mathrm{s}, \mathrm{NH}\right.$, ex $\left.\mathrm{D}_{2} \mathrm{O}\right) \cdot{ }^{13} \mathrm{C}$ NMR (DMSO- $\left.\boldsymbol{d}_{6}\right): 167.27$, $162.80,160.39,146.04,145.44,141.39,132.84,132.81,130.46$, $130.38,129.37,124.96,116.71,114.93,114.72,99.23,59.50,31.89$, 18.39, 14.28, 14.19. $\mathrm{MW}=483.5603$. Anal. $\left(\mathrm{C}_{25} \mathrm{H}_{26} \mathrm{FN}_{3} \mathrm{O}_{4} \mathrm{~S}\right) \mathrm{C}, \mathrm{H}, \mathrm{N}$.

7.1.3.5. Diethyl 4-[2-chloro-6-(4-fluorophenyl)imidazo[2,1b] [1,3]thiazol-5-yl]-2,6-dimethyl-1,4-dihydropyridine-3,5dicarboxylate (14)

27\% yield, mp $195^{\circ} \mathrm{C}$. IR: $3192,1704,1659,1207,1113 .{ }^{1} \mathbf{H}$ NMR (DMSO-d $\left.\boldsymbol{d}_{\mathbf{6}}\right): 0.90\left(6 \mathrm{H}, \mathrm{t}, \mathrm{COOCH}_{2} \mathrm{CH}_{3}, \mathrm{~J}=7.0\right), 2.07\left(6 \mathrm{H}, \mathrm{s}, \mathrm{CH}_{3}\right)$, $3.82\left(4 \mathrm{H}, \mathrm{q}, \mathrm{COOCH}_{2} \mathrm{CH}_{3}, \mathrm{~J}=7.0\right), 5.37(1 \mathrm{H}, \mathrm{s}, \mathrm{dhp}), 7.19(2 \mathrm{H}, \mathrm{t}$, ar-2,6, J=8.5), $7.53(2 \mathrm{H}, \mathrm{dd}, \operatorname{ar}-3,5, \mathrm{~J}=8.5), 7.92(1 \mathrm{H}, \mathrm{s}, \mathrm{th}), 8.95$ $\left(1 \mathrm{H}, \mathrm{s}, \mathrm{NH}\right.$, ex $\left.\mathrm{D}_{2} \mathrm{O}\right) .{ }^{13} \mathbf{C}$ NMR (DMSO-d $)$ ): 166.69, 162,57, 160,15, $145.35,142,74,142,65,131.71,130,66,130.39,130.31,119.37$, $116.00, \quad 114.62, \quad 114.42, \quad 98.83, \quad 59.13, \quad 31.45, \quad 17.95,13.85$. $\mathrm{MW}=503.9786$. Anal. $\left(\mathrm{C}_{24} \mathrm{H}_{23} \mathrm{ClFN}_{3} \mathrm{O}_{4} \mathrm{~S}\right) \mathrm{C}, \mathrm{H}, \mathrm{N}$.

7.1.3.6. Diethyl 4-[2-bromo-6-(4-fluorophenyl)imidazo[2,1-

b][1,3]thiazol-5-yl]-2,6-dimethyl-1,4-dihydropyridine-3,5dicarboxylate (15)

13\% yield, mp $185^{\circ} \mathrm{C}$. IR: $3192,1702,1659,1206,1113 .{ }^{1} \mathbf{H}$ NMR (DMSO-d $\left.\boldsymbol{d}_{\mathbf{6}}\right): 0.89\left(6 \mathrm{H}, \mathrm{t}, \mathrm{COOCH}_{2} \mathrm{CH}_{3}, \mathrm{~J}=7.0\right), 2.07\left(6 \mathrm{H}, \mathrm{s}, \mathrm{CH}_{3}\right)$, $3.82\left(4 \mathrm{H}, \mathrm{q}, \mathrm{COOCH}_{2} \mathrm{CH}_{3}, \mathrm{~J}=7.0\right), 5.37(1 \mathrm{H}, \mathrm{s}, \mathrm{dhp}), 7.18(2 \mathrm{H}, \mathrm{t}$, ar-2,6, J=8.7), $7.53(2 \mathrm{H}, \mathrm{dd}, \operatorname{ar}-3,5, \mathrm{~J}=8.7), 7.91(1 \mathrm{H}, \mathrm{s}, \mathrm{th}), 8.73$ $\left(1 \mathrm{H}, \mathrm{s}, \mathrm{NH}\right.$, ex $\left.\mathrm{D}_{2} \mathrm{O}\right) .{ }^{13} \mathrm{C}$ NMR (DMSO-d $)$ ): 166.71, 162.55, 160.14, $145.25,144.76,141.91,131.72,130.49,130.35,130.27,121.41$, 114.57, 114.36, 99.19, 98.90, 59.11, 31.50, 17.88, 13.81. $\mathrm{MW}=548.4296$. Anal. $\left(\mathrm{C}_{24} \mathrm{H}_{23} \mathrm{FBrN}_{3} \mathrm{O}_{4} \mathrm{~S}\right) \mathrm{C}, \mathrm{H}, \mathrm{N}$.

7.1.3.7. Diethyl 4-[6-(3,4-difluorophenyl)imidazo[2,1-b][1,3]thiazol5-yl]-2,6-dimethyl-1,4-dihydropyridine-3,5-dicarboxylate (16)

$16 \%$ yield, $\mathrm{mp} 175^{\circ} \mathrm{C}$. IR: $3069,1701,1660,1211,1114 .{ }^{1}$ H NMR (DMSO-d d $\left._{6}\right): 0.86\left(6 \mathrm{H}, \mathrm{t}, \mathrm{COOCH}_{2} \mathrm{CH}_{3}, \mathrm{~J}=7.0\right), 2.16\left(6 \mathrm{H}, \mathrm{s}, \mathrm{CH}_{3}\right)$, $3.80\left(4 \mathrm{H}, \mathrm{q}, \mathrm{COOCH}_{2} \mathrm{CH}_{3}, \mathrm{~J}=7.0\right), 5.56(1 \mathrm{H}, \mathrm{s}, \mathrm{dhp}), 7.30(1 \mathrm{H}, \mathrm{d}, \mathrm{th}$, $\mathrm{J}=4.4), 7.43(1 \mathrm{H}, \mathrm{d}$, th, $\mathrm{J}=4.4), 7.48(1 \mathrm{H}, \mathrm{m}, \mathrm{ar}), 7.58(1 \mathrm{H}, \mathrm{m}$, ar $)$, $7.78\left(1 \mathrm{H}, \mathrm{m}\right.$, ar), $8.95\left(1 \mathrm{H}, \mathrm{s}, \mathrm{NH}\right.$, ex $\left.\mathrm{D}_{2} \mathrm{O}\right) .{ }^{13} \mathbf{C}$ NMR $(\mathbf{1 0 1} \mathbf{M H z}$, DMSO- $\boldsymbol{d}_{\mathbf{6}}$ ): $166.77,146.97,145.35,140,53,129.12,124.87,119.35$, $116.95,116.78,116.67,116.49,113.12,98.47,59.18,31.51,30.68$, 18.01, 13.82. $\mathrm{MW}=487.5236$. Anal. $\left(\mathrm{C}_{24} \mathrm{H}_{23} \mathrm{~F}_{2} \mathrm{~N}_{3} \mathrm{O}_{4} \mathrm{~S}\right) \mathrm{C}, \mathrm{H}, \mathrm{N}$.

7.1.3.8. Diethyl 4-[6-(2,6-difluorophenyl)imidazo[2,1-b][1,3]thiazol5-yl]-2,6-dimethyl-1,4-dihydropyridine-3,5-dicarboxylate (17)

$31 \%$ yield, mp $254^{\circ} \mathrm{C}$. IR: $3186,1698,1646,1272,1097 .{ }^{1} \mathbf{H}$ NMR (DMSO-d d $\left._{6}\right): 0.93\left(6 \mathrm{H}, \mathrm{t}, \mathrm{COOCH}_{2} \mathrm{CH}_{3}, \mathrm{~J}=7.0\right), 1.93\left(6 \mathrm{H}, \mathrm{s}, \mathrm{CH}_{3}\right)$, $3.90\left(4 \mathrm{H}, \mathrm{q}, \mathrm{COOCH}_{2} \mathrm{CH}_{3}, \mathrm{~J}=7.0\right), 5.09(1 \mathrm{H}, \mathrm{s}, \mathrm{dhp}), 7.08(2 \mathrm{H}, \mathrm{t}, \mathrm{ar}$, $\mathrm{J}=7.5), 7.25(1 \mathrm{H}, \mathrm{d}$, th, $\mathrm{J}=4.4), 7.45(1 \mathrm{H}, \mathrm{q}, \mathrm{ar}, \mathrm{J}=7.5), 7.95(1 \mathrm{H}, \mathrm{d}$, th, $\mathrm{J}=4.4), 8.06\left(1 \mathrm{H}, \mathrm{s}, \mathrm{NH}\right.$, ex $\left.\mathrm{D}_{2} \mathrm{O}\right) \cdot{ }^{13} \mathrm{C}$ NMR (DMSO- $\left.\boldsymbol{d}_{6}\right)$ : 166.61 , $162.20,159.75,145.67,145.02,132.72,131.53,131.05,130.83$, $120.01,111.48,111.27,111.01,98.40,58.84,30.69,17.76,14.05$. $\mathrm{MW}=487.5236$. Anal. $\left(\mathrm{C}_{24} \mathrm{H}_{23} \mathrm{~F}_{2} \mathrm{~N}_{3} \mathrm{O}_{4} \mathrm{~S}\right) \mathrm{C}, \mathrm{H}, \mathrm{N}$.
7.1.3.9. Diethyl 2,6-dimethyl-4-[6-(2,4,5-

trifluorophenyl)imidazo[2,1-b][1,3]thiazol-5-yl]-1,4-

dihydropyridine-3,5-dicarboxylate (18)

$15 \%$ yield, mp $175^{\circ} \mathrm{C}$. IR: $3262,1700,1659,1209,1108 .{ }^{1} \mathbf{H}$ NMR (DMSO-d $\left.)_{6}\right): 0.94\left(6 \mathrm{H}, \mathrm{t}, \mathrm{COOCH}_{2} \mathrm{CH}_{3}, \mathrm{~J}=7.2\right), 1.99\left(6 \mathrm{H}, \mathrm{s}, \mathrm{CH}_{3}\right)$, $3.90\left(4 \mathrm{H}, \mathrm{q}, \mathrm{COOCH}_{2} \mathrm{CH}_{3}, \mathrm{~J}=7.2\right), 5.11(1 \mathrm{H}, \mathrm{s}, \mathrm{dhp}), 7.17(1 \mathrm{H}, \mathrm{m}, \mathrm{ar})$, $7.27(1 \mathrm{H}, \mathrm{d}, \mathrm{th}, \mathrm{J}=4.6), 7.54(1 \mathrm{H}, \mathrm{m}, \mathrm{ar}), 7.89(1 \mathrm{H}, \mathrm{d}, \mathrm{th}, \mathrm{J}=4.6), 8.37$ $\left(1 \mathrm{H}, \mathrm{s}, \mathrm{NH}\right.$, ex $\left.\mathrm{D}_{2} \mathrm{O}\right) .{ }^{13} \mathrm{C}$ NMR (DMSO-d $)$ : $166.58,145.55,144.91$, $136.13,132.00,120.02,119.86,111.99,105.84,105.63,105.54$, $105.34,98.91,64.84,58.95,30.78,17.68,13.96 . \mathrm{MW}=505.5138$. Anal. $\left(\mathrm{C}_{24} \mathrm{H}_{22} \mathrm{~F}_{3} \mathrm{~N}_{3} \mathrm{O}_{4} \mathrm{~S}\right) \mathrm{C}, \mathrm{H}, \mathrm{N}$.

7.1.3.10. Diethyl 4-[6-(4-chlorophenyl)imidazo[2,1-b][1,3]thiazol-5yl]-2,6-dimethyl-1,4-dihydropyridine-3,5-dicarboxylate (19)

$20 \%$ yield, mp $168^{\circ} \mathrm{C}$. IR: $3187,1702,1659,1208,1114 .{ }^{1} \mathbf{H}$ NMR (DMSO-d $\left.)_{6}\right): 0.84\left(6 \mathrm{H}, \mathrm{t}, \mathrm{COOCH}_{2} \mathrm{CH}_{3}, \mathrm{~J}=6.8\right), 2.15\left(6 \mathrm{H}, \mathrm{s}, \mathrm{CH}_{3}\right)$, $3.77\left(4 \mathrm{H}, \mathrm{q}, \mathrm{COOCH}_{2} \mathrm{CH}_{3}, \mathrm{~J}=6.8\right), 5.58(1 \mathrm{H}, \mathrm{s}, \mathrm{dhp}), 7.27(1 \mathrm{H}, \mathrm{d}$, th, $\mathrm{J}=4.6), 7.43(1 \mathrm{H}, \mathrm{d}$, th, $\mathrm{J}=4.6), 7.44(2 \mathrm{H}, \mathrm{d}, \mathrm{ar}, \mathrm{J}=8.4), 7.79(2 \mathrm{H}, \mathrm{d}$, ar, $\mathrm{J}=8.4), 8.91\left(1 \mathrm{H}, \mathrm{s}, \mathrm{NH}\right.$, ex $\left.\mathrm{D}_{2} \mathrm{O}\right) .{ }^{13} \mathrm{C}$ NMR (DMSO-d $\left.)_{6}\right): 166.71$, $146.86,145.13,141.45,134.70,131.20,129.60,129.09,127.62$, $119.34,112.73,98.58,59.03,31.57,17.90,13.80 . \mathrm{MW}=485.9886$. Anal. $\left(\mathrm{C}_{24} \mathrm{H}_{24} \mathrm{ClN}_{3} \mathrm{O}_{4} \mathrm{~S}\right) \mathrm{C}, \mathrm{H}, \mathrm{N}$.

7.1.3.11. Diethyl 4-[2-chloro-6-(4-chlorophenyl)imidazo[2,1b][1,3]thiazol-5-yl]-2,6-dimethyl-1,4-dihydropyridine-3,5dicarboxylate (20)

$35 \%$ yield, $\mathrm{mp} 208^{\circ} \mathrm{C}$. IR: $3229,1701,1685,1208,1114 .{ }^{\mathbf{1}} \mathbf{H}$ NMR (DMSO-d $\left.)_{6}\right): 0.88\left(6 \mathrm{H}, \mathrm{t}, \mathrm{COOCH}_{2} \mathrm{CH}_{3}, \mathrm{~J}=7.1\right), 2.10\left(6 \mathrm{H}, \mathrm{s}, \mathrm{CH}_{3}\right)$, $3.82\left(4 \mathrm{H}, \mathrm{q}, \mathrm{COOCH}_{2} \mathrm{CH}_{3}, \mathrm{~J}=7.1\right), 5.43(1 \mathrm{H}, \mathrm{s}, \mathrm{dhp}), 7.42(2 \mathrm{H}, \mathrm{d}, \mathrm{ar}$, $\mathrm{J}=8.4), 7.59(2 \mathrm{H}, \mathrm{d}, \mathrm{ar}, \mathrm{J}=8.4), 7.89(1 \mathrm{H}, \mathrm{s}, \mathrm{th}), 8.82(1 \mathrm{H}, \mathrm{s}, \mathrm{NH}, \mathrm{ex}$ $\left.\mathrm{D}_{2} \mathrm{O}\right) .{ }^{13} \mathbf{C}$ NMR (DMSO-d ( $_{6}$ : 166.61, 145.36, 143.07, 141.10, 134.10, $131.51,130.80,129.82,127.66,119.27,116,21,98.74,59.11,31.63$, 17.91, 13.79. $\mathrm{MW}=520.4337$. Anal. $\left(\mathrm{C}_{24} \mathrm{H}_{23} \mathrm{Cl}_{2} \mathrm{~N}_{3} \mathrm{O}_{4} \mathrm{~S}\right) \mathrm{C}, \mathrm{H}, \mathrm{N}$.

7.1.3.12. Diethyl 4-[2-chloro-6-(4-nitrophenyl)imidazo[2,1b][1,3]thiazol-5-yl]-2,6-dimethyl-1,4-dihydropyridine-3,5dicarboxylate (21)

19\% yield, mp $171^{\circ} \mathrm{C}$. IR: $3229,1694,1215,1120,1022 .{ }^{1} \mathbf{H}$ NMR (DMSO-d $\left.)_{6}\right): 0.87\left(6 \mathrm{H}, \mathrm{t}, \mathrm{COOCH}_{2} \mathrm{CH}_{3}, \mathrm{~J}=7.0\right), 2.12\left(6 \mathrm{H}, \mathrm{s}, \mathrm{CH}_{3}\right)$, $3.81\left(4 \mathrm{H}, \mathrm{q}, \mathrm{COOCH} \mathrm{CH}_{3}, \mathrm{~J}=7.0\right), 5.51(1 \mathrm{H}, \mathrm{s}, \mathrm{dhp}), 7.88(2 \mathrm{H}, \mathrm{d}, \mathrm{ar}$, $\mathrm{J}=8.8), 7.96(1 \mathrm{H}, \mathrm{s}, \mathrm{th}), 8.25(2 \mathrm{H}, \mathrm{d}$, ar, $\mathrm{J}=8.8), 8.91(1 \mathrm{H}, \mathrm{s}, \mathrm{NH}$, ex $\left.\mathrm{D}_{2} \mathrm{O}\right) .{ }^{13} \mathbf{C}$ NMR (DMSO-d ${ }_{6}$ ): 166.53, 145.88, 145.73, 143.83, 141.99, 140.03, 132.37, 128.84, 123.07, 119.39, 117.09, 98.60, 59.23, 31.99, 17.99, 13.81. $\mathrm{MW}=530.9857$. Anal. $\left(\mathrm{C}_{24} \mathrm{H}_{23} \mathrm{ClN}_{4} \mathrm{O}_{6} \mathrm{~S}\right) \mathrm{C}, \mathrm{H}, \mathrm{N}$.

7.1.3.13. Diethyl 4-[2-fluoro-6-(4-nitrophenyl)imidazo[2,1b] [1,3]thiazol-5-yl]-2,6-dimethyl-1,4-dihydropyridine-3,5dicarboxylate (22)

$21 \%$ yield, mp $165^{\circ} \mathrm{C}$. IR: $3353,1698,1596,1206,1104 .{ }^{1} \mathbf{H}$ NMR (DMSO-d $\left.)_{6}\right): 0.85\left(6 \mathrm{H}, \mathrm{t}, \mathrm{COOCH}_{2} \mathrm{CH}_{3}, \mathrm{~J}=7.0\right), 2.14\left(6 \mathrm{H}, \mathrm{s}, \mathrm{CH}_{3}\right)$, $3.80\left(4 \mathrm{H}, \mathrm{q}, \mathrm{COOCH}_{2} \mathrm{CH}_{3}, \mathrm{~J}=7.0\right), 5.53(1 \mathrm{H}, \mathrm{s}, \mathrm{dhp}), 7.77(1 \mathrm{H}, \mathrm{s}, \mathrm{th})$, $7.95(2 \mathrm{H}, \mathrm{d}, \mathrm{ar}, \mathrm{J}=8.8), 8.26(2 \mathrm{H}, \mathrm{d}$, ar, $\mathrm{J}=8.8), 8.93(1 \mathrm{H}, \mathrm{s}, \mathrm{NH}$, ex $\left.\mathrm{D}_{2} \mathrm{O}\right) .{ }^{13} \mathbf{C}$ NMR (DMSO-d ( $_{\mathbf{6}}$ : 166.95, 154.74, 151.92, 146.21, 146.16, $142.52,139.06,133.04,129.05,123.51,105.93,105.67,98.81,59.63$, 32.37, 18.45, 14.28. $\mathrm{MW}=514.5307$. Anal. $\left(\mathrm{C}_{24} \mathrm{H}_{23} \mathrm{FN}_{4} \mathrm{O}_{6} \mathrm{~S}\right) \mathrm{C}, \mathrm{H}, \mathrm{N}$. 
7.1.3.14. Diethyl 4-[2-chloro-6-(2,4-dichloro-5-

nitrophenyl)imidazo[2,1-b][1,3]thiazol-5-yl]-2,6-dimethyl-1,4-

dihydropyridine-3,5-dicarboxylate (23)

$32 \%$ yield, mp $165^{\circ}$ C.IR: $3201,1696,1657,1205,1115 .{ }^{1} \mathbf{H}$ NMR (DMSO-d d $\left._{6}\right): 0.97\left(6 \mathrm{H}, \mathrm{t}, \mathrm{COOCH}_{2} \mathrm{CH}_{3}, \mathrm{~J}=7.2\right), 1.95\left(6 \mathrm{H}, \mathrm{s}, \mathrm{CH}_{3}\right)$, $3.94\left(4 \mathrm{H}, \mathrm{q}, \mathrm{COOCH}_{2} \mathrm{CH}_{3}, \mathrm{~J}=7.2\right), 5.04(1 \mathrm{H}, \mathrm{s}, \mathrm{dhp}), 7.83(1 \mathrm{H}, \mathrm{s}, \mathrm{th})$, $8.08(1 \mathrm{H}, \mathrm{s}, \mathrm{ar}), 8.35(1 \mathrm{H}, \mathrm{s}, \mathrm{ar}), 8.42\left(1 \mathrm{H}, \mathrm{s}, \mathrm{NH}\right.$, ex $\left.\mathrm{D}_{2} \mathrm{O}\right) .{ }^{13} \mathbf{C} \mathbf{N M R}$

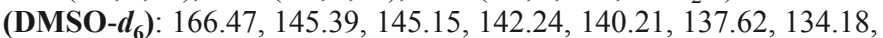
132.96, 131.68, 128.89, 126.76, 119.91, 115.97, 98.86, 59.10, 30.65, 17.64, 13.88. $\mathrm{MW}=623.8979$. Anal. $\left(\mathrm{C}_{26} \mathrm{H}_{21} \mathrm{Cl}_{3} \mathrm{~N}_{4} \mathrm{O}_{6} \mathrm{~S}\right) \mathrm{C}, \mathrm{H}, \mathrm{N}$.

7.1.3.15. Diethyl 4-[6-(2,4-dichloro-5-nitrophenyl)-2ethylimidazo[2,1-b][1,3]thiazol-5-yl]-2,6-dimethyl-1,4dihydropyridine-3,5-dicarboxylate (24)

$19 \%$ yield, mp $231^{\circ} \mathrm{C}$. IR: $3180,1696,1665,1206,1117 .{ }^{1} \mathbf{H}$ NMR (DMSO-d d ): 0.97 (6H, t, $\left.\mathrm{COOCH}_{2} \mathrm{CH}_{3}, \mathrm{~J}=7.0\right), 1.28\left(3 \mathrm{H}, \mathrm{t}, \mathrm{CH}_{2} \mathrm{CH}_{3}\right.$, $\mathrm{J}=7.3), 1.96\left(6 \mathrm{H}, \mathrm{s}, \mathrm{CH}_{3}\right), 2.84\left(2 \mathrm{H}, \mathrm{q}, \mathrm{CH}_{2} \mathrm{CH}_{3}, \mathrm{~J}=7.3\right), 3.94(4 \mathrm{H}$, q, $\left.\mathrm{COOCH}_{2} \mathrm{CH}_{3}, \mathrm{~J}=7.0\right), 5.04(1 \mathrm{H}, \mathrm{s}, \mathrm{dhp}), 7.63(1 \mathrm{H}, \mathrm{s}, \mathrm{th}), 7.81$ $(1 \mathrm{H}, \mathrm{s}$, ar $), 8.07(1 \mathrm{H}, \mathrm{s}$, ar $), 8.34\left(1 \mathrm{H}, \mathrm{s}, \mathrm{NH}\right.$, ex $\left.\mathrm{D}_{2} \mathrm{O}\right) .{ }^{13} \mathbf{C}$ NMR

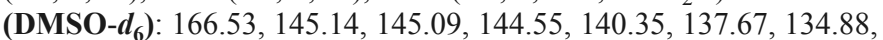
131.74, 131.64, 131.33, 128.92, 126.49, 115.68, 99.10, 59.05, 30.63, 21.51, 17.67, 14.93, 13.98. $\mathrm{MW}=593.4844$. Anal. $\left(\mathrm{C}_{26} \mathrm{H}_{26} \mathrm{Cl}_{2} \mathrm{~N}_{4} \mathrm{O}_{6} \mathrm{~S}\right)$ $\mathrm{C}, \mathrm{H}, \mathrm{N}$.

7.1.3.16. Diallyl 4-[6-(2,5-dimethoxy-4-nitrophenyl)imidazo[2,1b] [1,3] thiazol-5-yl]-2,6-dimethyl-1,4-dihydropyridine-3,5-

dicarboxylate (30)

$10 \%$ yield, mp $200^{\circ} \mathrm{C}$. IR: $3185,1693,1666,1202,1114 .{ }^{1} \mathbf{H}$ NMR (DMSO-d d $\left._{6}\right) 1.95\left(6 \mathrm{H}, \mathrm{s}, \mathrm{CH}_{3}\right), 3.57\left(3 \mathrm{H}, \mathrm{s}, \mathrm{OCH}_{3}\right), 3.82(3 \mathrm{H}, \mathrm{s}$, $\left.\mathrm{OCH}_{3}\right), 4.43\left(4 \mathrm{H}, \mathrm{m}, \mathrm{CH} \mathrm{CH}_{2}=\mathrm{CH}_{2}\right), 4.97\left(4 \mathrm{H}, \mathrm{m}, \mathrm{CH}_{2} \mathrm{CH}=\mathrm{CH}_{2}\right)$, $5.16(1 \mathrm{H}, \mathrm{s}, \mathrm{dhp}), 5.71\left(2 \mathrm{H}, \mathrm{m}, \mathrm{CH}_{2} \mathrm{CH}=\mathrm{CH}_{2}\right), 6.92(1 \mathrm{H}, \mathrm{s}, \mathrm{ar}), 7.18$ $(1 \mathrm{H}, \mathrm{d}$, th, $\mathrm{J}=4.6), 7.48(1 \mathrm{H}, \mathrm{s}, \mathrm{ar}), 7.79(1 \mathrm{H}, \mathrm{d}, \mathrm{th}, \mathrm{J}=4.6), 8.41(1 \mathrm{H}, \mathrm{s}$, NH, ex D $\mathrm{D}_{2} \mathrm{O}$ ). ${ }^{13}$ C NMR (DMSO- $\boldsymbol{d}_{\mathbf{6}}$ ): 166.33, 151.09, 145.68, 145.51, $145.24,139.09,138.06,132.97,131.39,130.71,119.64,118.09$, $116.73,111.42,106.83,98.65,63.62,56.72,55.79,30.91,17.77$. $\mathrm{MW}=580.6142$. Anal. $\left(\mathrm{C}_{28} \mathrm{H}_{28} \mathrm{~N}_{4} \mathrm{O}_{8} \mathrm{~S}\right) \mathrm{C}, \mathrm{H}, \mathrm{N}$.

7.1.3.17. Dimethyl 4-[6-(5-bromo-2,4-dimethoxyphenyl)imidazo[2,1b] [1,3]thiazol-5-yl]-2,6-dimethyl-1,4-dihydropyridine-3,5-

dicarboxylate (32)

$10 \%$ yield, $\operatorname{mp} 232^{\circ} \mathrm{C}$. IR: $3425,1693,1644,1277,1207 .{ }^{1} \mathbf{H}$ NMR (DMSO-d $): 1.99\left(6 \mathrm{H}, \mathrm{s}, \mathrm{CH}_{3}\right), 3.43\left(6 \mathrm{H}, \mathrm{s}, \mathrm{COOCH}_{3}\right), 3.61(3 \mathrm{H}, \mathrm{s}$, $\left.\mathrm{OCH}_{3}\right), 3.92\left(3 \mathrm{H}, \mathrm{s}, \mathrm{OCH}_{3}\right), 5.08(1 \mathrm{H}, \mathrm{s}, \mathrm{dhp}), 6.71(1 \mathrm{H}, \mathrm{s}, \mathrm{ar}), 7.00$ $(1 \mathrm{H}, \mathrm{s}, \mathrm{ar}), 7.18(1 \mathrm{H}, \mathrm{d}, \mathrm{th}, \mathrm{J}=4.2), 7.80(1 \mathrm{H}, \mathrm{d}, \mathrm{th}, \mathrm{J}=4.2), 8.27(1 \mathrm{H}, \mathrm{s}$, NH, ex $\left.\mathrm{D}_{2} \mathrm{O}\right) .{ }^{13} \mathbf{C}$ NMR (DMSO-d N $_{\mathbf{6}}: 167.24,158.43,156.01,144.93$, $144.83,140.04,134.49,130.77,119.42,118.04,111.15,99.25,98.50$, $96.75,56.35,55.41,50.56,30.77,17.76 . \mathrm{MW}=562.4376$. Anal. $\left(\mathrm{C}_{24} \mathrm{H}_{24} \mathrm{BrN}_{3} \mathrm{O}_{6} \mathrm{~S}\right) \mathrm{C}, \mathrm{H}, \mathrm{N}$.

7.1.3.18. Diethyl 4-[6-(2,5-dimethoxyphenyl)-2-methylimidazo[2,1b] [1,3]thiazol-5-yl]-2,6-dimethyl-1,4-dihydropyridine-3,5-

dicarboxylate (34)

17\% yield, mp $160^{\circ} \mathrm{C}$. IR: $3180,1694,1660,1205,1114 .{ }^{1} \mathbf{H}$ NMR (DMSO-d $\left.\boldsymbol{d}_{6}\right): 0.97\left(6 \mathrm{H}, \mathrm{t}, \mathrm{COOCH}_{2} \mathrm{CH}_{3}, \mathrm{~J}=7.0\right), 1.90\left(6 \mathrm{H}, \mathrm{s}, \mathrm{CH}_{3}\right)$, $2.44\left(3 \mathrm{H}, \mathrm{s}, \mathrm{CH}_{3}\right), 3.48\left(3 \mathrm{H}, \mathrm{s}, \mathrm{OCH}_{3}\right), 3.69\left(3 \mathrm{H}, \mathrm{s}, \mathrm{OCH}_{3}\right), 3.90$ $\left(4 \mathrm{H}, \mathrm{q}, \mathrm{COOCH}_{2} \mathrm{CH}_{3}, \mathrm{~J}=7.0\right), 4.99(1 \mathrm{H}, \mathrm{s}, \mathrm{dhp}), 6.44(1 \mathrm{H}, \mathrm{s}, \mathrm{ar})$, $6.84(2 \mathrm{H}, \mathrm{s}, \mathrm{ar}), 7.61(1 \mathrm{H}, \mathrm{s}, \mathrm{th}), 8.01\left(1 \mathrm{H}, \mathrm{s}, \mathrm{NH}\right.$, ex $\left.\mathrm{D}_{2} \mathrm{O}\right) .{ }^{13} \mathrm{C}$ NMR (DMSO- $\boldsymbol{d}_{6}$ ): $166.90,152.17,151.87,144.68,143.51,140.20$, $130.37,125.25,122.64,117.81,116.71,113.47,110.86,98.73,58.78$,
$55.24,55.17,30.81,17.73,13.95,13.50 . \mathrm{MW}=525.6218$. Anal. $\left(\mathrm{C}_{27} \mathrm{H}_{31} \mathrm{~N}_{3} \mathrm{O}_{6} \mathrm{~S}\right) \mathrm{C}, \mathrm{H}, \mathrm{N}$.

7.1.3.19. Diethyl 4-[2-bromo-6-(2,5-dimethoxyphenyl)imidazo[2,1b] [1,3]thiazol-5-yl]-2,6-dimethyl-1,4-dihydropyridine-3,5dicarboxylate (35)

$22 \%$ yield, $\mathrm{mp} 214^{\circ} \mathrm{C}$. IR: $3390,1695,1658,1204,1117 .{ }^{\mathbf{1}} \mathbf{H}$ NMR (DMSO-d $\left.)_{6}\right): 0.98\left(6 \mathrm{H}, \mathrm{t}, \mathrm{COOCH}_{2} \mathrm{CH}_{3}, \mathrm{~J}=7.0\right), 1.90\left(6 \mathrm{H}, \mathrm{s}, \mathrm{CH}_{3}\right)$, $3.32\left(3 \mathrm{H}, \mathrm{s}, \mathrm{OCH}_{3}\right), 3.47\left(3 \mathrm{H}, \mathrm{s}, \mathrm{OCH}_{3}\right), 3.90\left(4 \mathrm{H}, \mathrm{q}, \mathrm{COOCH}_{2} \mathrm{CH}_{3}\right.$, $\mathrm{J}=7.0), 5.01(1 \mathrm{H}, \mathrm{s}, \mathrm{dhp}), 6.44(1 \mathrm{H}, \mathrm{s}, \mathrm{ar}), 6.87(2 \mathrm{H}, \mathrm{s}, \mathrm{ar}), 8.03(1 \mathrm{H}, \mathrm{s}$, $\mathrm{NH}$, ex $\left.\mathrm{D}_{2} \mathrm{O}\right), 8.23(1 \mathrm{H}, \mathrm{s}, \mathrm{th}) .{ }^{13} \mathbf{C}$ NMR (DMSO- $\left.\boldsymbol{d}_{6}\right)$ : $166.79,152.22$, $151.78,145.00,142.95,140.48,131.45,124.50,121.85,117.66$, $113.75,110.91,98.54,97.60,58.84,55.27,55.21,30.80,17.71,13.89$. $\mathrm{MW}=590.4911$. Anal. $\left(\mathrm{C}_{26} \mathrm{H}_{28} \mathrm{BrN}_{3} \mathrm{O}_{6} \mathrm{~S}\right) \mathrm{C}, \mathrm{H}, \mathrm{N}$.

7.1.3.20. Diethyl 4-[2-bromo-6-(3,4-dimethoxyphenyl)imidazo[2,1b][1,3]thiazol-5-yl]-2,6-dimethyl-1,4-dihydropyridine-3,5-

dicarboxylate (36)

$18 \%$ yield, mp $189^{\circ} \mathrm{C}$. IR: $3184,1699,1656,1203,1025 .{ }^{1} \mathbf{H}$ NMR (DMSO-d d $\left._{6}\right): 0.89\left(6 \mathrm{H}, \mathrm{t}, \mathrm{COOCH}_{2} \mathrm{CH}_{3}, \mathrm{~J}=7.2\right), 2.09\left(6 \mathrm{H}, \mathrm{s}, \mathrm{CH}_{3}\right)$, $3.74\left(3 \mathrm{H}, \mathrm{s}, \mathrm{OCH}_{3}\right), 3.78\left(3 \mathrm{H}, \mathrm{s}, \mathrm{OCH}_{3}\right), 3.84\left(4 \mathrm{H}, \mathrm{q}, \mathrm{COOCH}_{2} \mathrm{CH}_{3}\right.$, $\mathrm{J}=7.2), 5.45(1 \mathrm{H}, \mathrm{s}, \mathrm{dhp}), 6.93(1 \mathrm{H}, \mathrm{d}$, ar, $\mathrm{J}=8.4), 7.13(1 \mathrm{H}, \mathrm{d}$, ar, $\mathrm{J}=8.4), 7.18(1 \mathrm{H}, \mathrm{s}, \mathrm{ar}), 7.80(1 \mathrm{H}, \mathrm{s}, \mathrm{th}), 8.77\left(1 \mathrm{H}, \mathrm{s}, \mathrm{NH}\right.$, ex $\left.\mathrm{D}_{2} \mathrm{O}\right) .{ }^{13} \mathbf{C}$

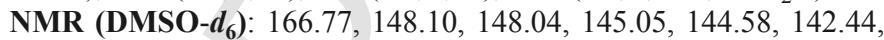
$129.64,128.02,121.24,120.78,112.40,111.24,98.92,98.77,59.06$, 55.56, 55.48, 31.55, 17.92, 13.79. $\mathrm{MW}=590.4911$. Anal. $\left(\mathrm{C}_{26} \mathrm{H}_{28} \mathrm{BrN}_{3} \mathrm{O}_{6} \mathrm{~S}\right) \mathrm{C}, \mathrm{H}, \mathrm{N}$.

7.1.3.21. Diethyl 4-[2-bromo-6-(3,5-dimethoxyphenyl)imidazo[2,1b][1,3]thiazol-5-yl]-2,6-dimethyl-1,4-dihydropyridine-3,5-

dicarboxylate (37)

$10 \%$ yield, mp $185^{\circ} \mathrm{C}$. IR: $3202,1693,1601,1204,1156 .{ }^{1} \mathbf{H}$ NMR (DMSO-d $\left.)_{6}\right): 0.89\left(6 \mathrm{H}, \mathrm{t}, \mathrm{COOCH}_{2} \mathrm{CH}_{3}, \mathrm{~J}=7.2\right), 2.09\left(6 \mathrm{H}, \mathrm{s}, \mathrm{CH}_{3}\right)$, $3.74\left(3 \mathrm{H}, \mathrm{s}, \mathrm{OCH}_{3}\right), 3.78\left(3 \mathrm{H}, \mathrm{s}, \mathrm{OCH}_{3}\right), 3.84\left(4 \mathrm{H}, \mathrm{q}, \mathrm{COOCH}_{2} \mathrm{CH}_{3}\right.$, $\mathrm{J}=7.2), 5.47(1 \mathrm{H}, \mathrm{s}, \mathrm{dhp}), 6.45(1 \mathrm{H}, \mathrm{s}, \mathrm{ar}), 6.78(2 \mathrm{H}, \mathrm{s}, \mathrm{ar}), 7.78(1 \mathrm{H}, \mathrm{s}$,

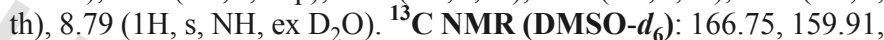
145.23, 144.78, 142.20, 137.03, 130.14, 121.18, 106.56, 99.42, 99.05, $98.65,59.10,55.16,31.57,17.92,13.79$. $\mathrm{MW}=590.4911$. Anal. $\left(\mathrm{C}_{26} \mathrm{H}_{28} \mathrm{BrN}_{3} \mathrm{O}_{6} \mathrm{~S}\right) \mathrm{C}, \mathrm{H}, \mathrm{N}$.

7.1.3.22. Diethyl 4-[6-(4-chloro-3-nitrophenyl)-2-methylimidazo[2,1b] [1,3]thiazol-5-yl]-2,6-dimethyl-1,4-dihydropyridine-3,5dicarboxylate (38)

$15 \%$ yield, $\mathrm{mp} 205^{\circ} \mathrm{C}$. IR: $3185,1695,1688,1203,1117 .{ }^{1} \mathbf{H}$ NMR (DMSO-d $\left.)_{6}\right): 0.84\left(6 \mathrm{H}, \mathrm{t}, \mathrm{COOCH}_{2} \mathrm{CH}_{3}, \mathrm{~J}=7.0\right), 2.18\left(6 \mathrm{H}, \mathrm{s}, \mathrm{CH}_{3}\right)$, $2.43\left(3 \mathrm{H}, \mathrm{s}, \mathrm{CH}_{3}\right), 3.80\left(4 \mathrm{H}, \mathrm{q}, \mathrm{COOCH}_{2} \mathrm{CH}_{3}, \mathrm{~J}=7.0\right), 5.57(1 \mathrm{H}, \mathrm{s}$, dhp), 7.21 (1H, s, th), $7.80(1 \mathrm{H}, \mathrm{d}$, ar, J=8.4), $8.12(1 \mathrm{H}, \mathrm{d}, \mathrm{ar}, \mathrm{J}=8.4)$, $8.40(1 \mathrm{H}, \mathrm{s}, \mathrm{ar}), 8.97\left(1 \mathrm{H}, \mathrm{s}, \mathrm{NH}\right.$, ex $\left.\mathrm{D}_{2} \mathrm{O}\right) .{ }^{13}$ C NMR (DMSO-d $\boldsymbol{d}_{6}$ ): $166.59,147.21,146.60,145.51,137.88,136.26,132.61,131.18$, $130.04,125.88,125.09,123.77,122.53,116.06,98.26,59.16,31.84$, 17.97, 13.71. $\mathrm{MW}=545.0125$. Anal. $\left(\mathrm{C}_{25} \mathrm{H}_{25} \mathrm{ClN}_{4} \mathrm{O}_{6} \mathrm{~S}\right) \mathrm{C}, \mathrm{H}, \mathrm{N}$.

7.1.3.23. Diethyl 4-[6-(4-bromo-3-nitrophenyl)imidazo[2,1b] [1,3]thiazol-5-yl]-2,6-dimethyl-1,4-dihydropyridine-3,5dicarboxylate (39)

$16 \%$ yield, mp $212{ }^{\circ} \mathrm{C}$. IR: $3183,1695,1670,1203,1114 .{ }^{\mathbf{1}} \mathbf{H}$ NMR (DMSO-d d $_{6}: 0.82\left(6 \mathrm{H}, \mathrm{t}, \mathrm{COOCH}_{2} \mathrm{CH}_{3}, \mathrm{~J}=7.1\right), 2.18\left(6 \mathrm{H}, \mathrm{s}, \mathrm{CH}_{3}\right)$, $3.78\left(4 \mathrm{H}, \mathrm{q}, \mathrm{COOCH}_{2} \mathrm{CH}_{3}, \mathrm{~J}=7.1\right), 5.63(1 \mathrm{H}, \mathrm{s}, \mathrm{dhp}), 7.34(1 \mathrm{H}$, $\mathrm{d}$, th, $\mathrm{J}=4.6), 7.43(1 \mathrm{H}, \mathrm{d}$, th, $\mathrm{J}=4.6), 7.95(1 \mathrm{H}, \mathrm{d}, \mathrm{ar}-5, \mathrm{~J}=8.4)$, $8.06(1 \mathrm{H}, \mathrm{dd}$, ar- $6, \mathrm{~J}=1.8, \mathrm{~J}=8.4), 8.41(1 \mathrm{H}, \mathrm{d}$, ar-2, $\mathrm{J}=1.8), 9.02$ 
$\left(1 \mathrm{H}, \mathrm{s}, \mathrm{NH}\right.$, ex $\left.\mathrm{D}_{2} \mathrm{O}\right) .{ }^{13} \mathbf{C}$ NMR (DMSO-d $)$ ): 166.58, 149.36, 147.42, $145.66,138.92,136.69,134.32,132.61,130.63,123.77,119.28$, $113.87,110.62,98.16,59.19,31.83,18.00,13.74$. $\mathrm{MW}=575.4367$. Anal. $\left(\mathrm{C}_{24} \mathrm{H}_{23} \mathrm{BrN}_{4} \mathrm{O}_{6} \mathrm{~S}\right) \mathrm{C}, \mathrm{H}, \mathrm{N}$.

\subsection{Assessment of neuroprotection}

\subsubsection{Cells cultures}

Human astrocytoma cell line U-373 MG cells (ATCC, Manassas, VA) were cultured as previously described [46]. For oxygen and glucose deprivation and reperfusion (OGD/R) experiments cells were harvested by trypsinization, seeded at 30000 cells $/ \mathrm{ml}$ in a $96-w e l l$ culture plates and grown for 24 or $48 \mathrm{~h}$ under standard conditions $\left(37^{\circ} \mathrm{C} /\right.$ $5 \% \mathrm{CO}_{2}$ ). OGD was then performed by replacing the culture medium with Dulbecco's Modified Eagle Medium (DMEM) containing no glucose and previously bubbled with a $95 \% \mathrm{~N}_{2} / 5 \% \mathrm{CO}_{2}$ gas mixture (nitrogen) for at least $1 \mathrm{~h}$ to eliminate oxygen in the medium. Plates were placed in an airtight chamber (C.B.S. Scientific Company, San Diego, $\mathrm{CA}$ ) and then equilibrated for $10 \mathrm{~min}$ with a continuous flux of nitrogen. The chamber was sealed and placed in an incubator at $37^{\circ} \mathrm{C}$ for $24 \mathrm{~h}$ Afterward the cells were returned to the normal culture media in a normal oxygen incubator for $16 \mathrm{~h}$ of reperfusion. Control cell cultures that were not deprived of oxygen and glucose were placed in normal oxygenated DMEM containing glucose. To assess neuroprotective effects, drugs were added during the reperfusion phase at $20 \mu \mathrm{M}$ final concentration. Each experiment was repeated at least four times.

\subsubsection{SHSY-5Y cells}

Human SH SY5Y neuroblastoma cells (ATCC, Manassas, VA) were grown as previously detailed [47]. For excitotoxicity-induced damage experiments cells were harvested by trypsinization, seeded at 80000 cells $/ \mathrm{ml}$ in a 96-well culture plates and grown for 24 or $48 \mathrm{~h}$ under standard conditions $\left(37^{\circ} \mathrm{C} / 5 \% \mathrm{CO}_{2}\right)$. L-Glutamate (GLU) stock solution was prepared by dissolving the aminoacid in $1 \mathrm{M} \mathrm{HCl}$ and by re-equilibrating the solution at $\mathrm{pH} 7.5$ before dilution to working concentrations with culture medium. Cells were exposed to $50 \mathrm{mM}$ GLU or $50 \mathrm{mM} \mathrm{GLU}+\mathbf{5 - 3 9}$ derivatives at $1 \mu \mathrm{M}$ or $20 \mu \mathrm{M}$ final concentration or left untreated for $24 \mathrm{~h}$ (controls). Each experiment was repeated at least four times.

\subsubsection{5-39 derivatives treatments}

Stock solutions of the compounds were prepared in DMSO $\left(10 \mathrm{mM}\right.$, kept at $\left.-20^{\circ} \mathrm{C}\right)$ and immediately before use, they were diluted with cells culture medium to the desired final concentration. Control cells were treated only with DMSO, which never exceeded $0.1 \%$.

\subsubsection{Cell viability: alamar blue assay (AB)}

U373-MG or SHSY-5Y cell viability was assessed with the fluorescent dye, alamarBlue (AB) (Invitrogen, Carlsbad, CA), following manufacturer's instructions. Briefly, $20 \mu \mathrm{l}$ of $\mathrm{AB}(1 \mathrm{mg} / \mathrm{mL})$ were added to each well containing $200 \mu \mathrm{l}$ cell supernatant. The microplates were further incubated for $4 \mathrm{~h}$ at $37^{\circ} \mathrm{C}$ and cell fluorescence was quantified using a Cytofluor 2350 fluorescence scanner (Millipore Corp, Bedford, MA) equipped with 530-560 nm excitation and $590 \mathrm{~nm}$ emission filters. $\mathrm{AB}$ assay provides an indication of the metabolic activity of cell cultures cytotoxicity being related to the decline in arbitrary fluorescence units (FUs) of treated cultures, as compared to control cultures [48].

\subsubsection{Rat brain cortical slices}

All animal care and experimental protocols conformed the ARRIVE guidelines as well as the European Union Guidelines for the Care and the Use of Laboratory Animals (European Union Directive 2010/63/EU) and were approved by the Italian Department of Health (813/2015-PR).

Male Wistar rats (Charles River Italia, Calco, Italy), weighing 250-350 g, were used. Before the experiments, animals were housed in groups of two/three per cage and acclimatized for at least 1 week in the laboratory animal facility, maintained at constant temperature $\left(21 \pm 2{ }^{\circ} \mathrm{C}\right)$ and humidity $(55 \pm 5 \%)$ with a $12 \mathrm{~h} \mathrm{light/dark} \mathrm{cycle.} \mathrm{Food}$ and water were provided ad libitum. The protocol used was already described elsewhere [49]. Briefly, after sacrifice the whole brain was rapidly removed, chilled to $4^{\circ} \mathrm{C}$ by immersion into cold ACSF (composition in $\mathrm{mM}: 120 \mathrm{NaCl}, 2.5 \mathrm{KCl}, 1.3 \mathrm{MgCl}_{2}, 1.0 \mathrm{NaH}_{2} \mathrm{PO}_{4}, 1.5$ $\mathrm{CaCl}_{2}, 26 \mathrm{NaHCO}_{3}, 11$ glucose, saturated with $95 \% \mathrm{O}_{2}-5 \% \mathrm{CO}_{2}$, with a final $\mathrm{pH}$ of 7.4 , osmolality $285-290 \mathrm{mOsmol}$ ). The cortex was dissected and cut into $400 \mu \mathrm{m}$-thickness slices by using a manual chopper (Stoelting Co., Wood Dale, IL, USA). Afterward, slices were maintained in oxygenated ACSF enriched with $400 \mu \mathrm{M}$ ascorbic acid for $1 \mathrm{~h}$ at room temperature to allow maximal recovery from slicing trauma). Cortical slices from a single brain were then placed in covered incubation flasks containing $2 \mathrm{~mL}$ ACSF continuously bubbled with a $95 \% \mathrm{O}_{2} / 5 \% \mathrm{CO}_{2}$ gas mixture and incubated at $37^{\circ} \mathrm{C}$ for an additional period of $30 \mathrm{~min}$. Afterward, OGD was carried out by incubating slices for $30 \mathrm{~min}$ into Artificial CerebroSpinal Fluid (ACSF) in which glucose was replaced by an equimolar amount of saccharose, and continuously bubbled with a $95 \% \mathrm{~N}_{2} / 5 \% \mathrm{CO}_{2}$ gas mixture. After the OGD phase, the ischemic-like solution was replaced with fresh, oxygenated ACSF for an additional $90 \mathrm{~min}$ period (reoxygenation phase). The protective effects of derivatives 5-9, 12, 14, 16, 18, 22, 24, 27, 28, 30, 33, 35-39 were investigated by adding them to ACSF during the entire reoxygenation phase at final concentration of $20 \mu \mathrm{M}$.

\subsubsection{Assessment of brain slices injury}

Cell damage was assessed by measuring the amount of LDH released into the ACSF during the entire reperfusion period [49]. In particular, LDH activity was determined spectrophotometrically via the rate of decrease in absorbance at $340 \mathrm{~nm}$ of NADH during its oxidation to $\mathrm{NAD}^{+}$and the concomitant reduction of pyruvate to lactate. Tissue water gain (TWG, tissue edema) was calculated as already described [50].

\subsubsection{Analysis of data}

Data are reported as Mean \pm E.S.M. and expressed as percent of recovery from injury which varies from 0 (no damage recovered) to $100 \%$ (totally recovered damage). Statistical analysis was performed by using one-way ANOVA followed Bonferroni post-test (GraphPad Software v.5, San Diego, CA, USA). In all comparisons, the level of statistical significance $(P)$ was set at 0.05 .

\subsection{Periferal functional studies}

All the experiment were conducted according to the guidelines set forth to EU Directive 2010/63/EU and to ARRIVE guidelines. The protocol was approved by the Institutional Ethics Committee of the University of Bologna (Protocol 21/79/14) and transmitted to the Ministry of Health. For details, please see Supporting Information. 


\section{Acknowledgment}

Supported by grants from University of Bologna.

$\begin{array}{ll}\text { Abbreviations } & \\ \text { LTCC } & \text { L-type Calcium channel } \\ \text { 1,4-DHPs } & \text { 1,4-dihydropyridines } \\ \text { GPILSM } & \text { guinea-pig ileum longitudinal smooth muscle } \\ \text { NMR } & \text { Nuclear Magnetic Resonance } \\ \text { DMSO } & \text { Dimethyl sulfoxide; } \\ \text { DMF } & \text { N,N-dimethylformamide; } \\ \text { SEM } & \text { Standard Error Mean } \\ \text { NMDA } & N \text {-methyl-D-aspartic acid } \\ \text { AMPA } & \alpha \text {-amino-3-hydroxy-5-methylisoxazole-4-propionate } \\ \text { KA } & \text { kainic acid } \\ \text { NOS } & \text { nitric oxide synthase } \\ \text { MTDL } & \text { multi target direct ligands } \\ \text { LDH } & \text { lactate dehydrogenase } \\ \text { OGD/R } & \text { oxygen glucose deprivation and reperfusion } \\ \text { GLU } & \text { L-Glutamate } \\ \text { CCBs } & \text { Calcium-channel blockers } \\ \text { ACSF } & \text { Artificial CerebroSpinal Fluid } \\ \text { DMEM } & \text { Dulbecco's Modified Eagle Medium }\end{array}$

\section{Appendix A. Supplementary data}

Supplementary data to this article can be found online at https:// doi.org/10.1016/j.ejmech.2019.02.075.

\section{References}

[1] C.W. Olanow, The pathogenesis of cell death in Parkinson's disease, Mov. Disord. 22 (2007) 335-342 https://doi.org/10.1002/mds.21675.

[2] J.M. Gil, A.C. Rego, Mechanisms of neurodegeneration in Huntington's disease, Eur. J. Neurosci. 27 (2008) 2803-2820 https://doi.org/10.1111/j.1460-9568. 2008.06310.x.

[3] A.S. Hazell, Excitotoxic mechanisms in stroke: an update of concepts and treatment strategies, Neurochem. Int. 50 (2007) 941-953 https://doi.org/10.1016/j. neuint.2007.04.026

[4] D. Banoa, M. Ankarcrona, Beyond the critical point: an overview of excitotoxicity, calcium overload and the downstream consequences, Neurosci. Lett. 663 (2018) 79-85 https://doi.org/10.1016/j.neulet.2017.08.048.

[5] J. Horn, R.J. de Haan, M. Vermeulen, P.G. Luiten, M. Limburg, Nimodipine in animal model experiments of focal cerebral ischemia: a systematic review, Stroke 32 (2001) 2433-2438 https://doi.org/10.1161/hs1001.096009.

[6] G.W. Zamponi, J. Striessnig, A. Koschak, A.C. Dolphin, The physiology, pathology, and pharmacology of voltage-gated calcium channels and their future therapeutic potential, Pharmacol. Rev. 67 (2015) 821-870 https://doi.org/10. 1124/pr.114.009654.

[7] P. Ioan, E. Carosati, M. Micucci, G. Cruciani, F. Broccatelli, B.S. Zhorov, A. Chiarini, R. Budriesi, 1,4-Dihydropyridine scaffold in medicinal chemistry, the story so far AnD perspectives. (Part 1): action in ion channels and GPCRs, Curr Med. Chem. 18 (2011) 4901-4922 https://doi.org/10.2174/ 092986712802884204.

[8] A. Zuccotti, S. Clementi, T. Reinbothe, A. Torrente, D.H. Vandael, A. Pirone, Structural and functional differences between L-type calcium channels: crucial issues for future selective targeting, Trends Pharmacol. Sci. 32 (2011) 366-375 https://doi.org/10.1016/j.tips.2011.02.012.

[9] G.W. Zamponi, Targeting voltage-gated calcium channels in neurological and psychiatric diseases, Nat. Rev. Drug Discov. 15 (2016) 19-34 https://doi.org/10. 1038/nrd.2015.5.

[10] N. Daschil, C. Humpel, Nifedipine and nimodipine protect dopaminergic substantia nigra neurons against axotomy-induced cell death in rat vibrosections via modulating inflammatory responses, Brain Res. 1581 (2014) 1-11 https://doi. org/10.1016/j.brainres.2014.07.014.

[11] E. Carosati, P. Ioan, M. Micucci, F. Broccatelli, G. Cruciani, B.S. Zhorov, A. Chiarini, R. Budriesi, 1,4-Dihydropyridine scaffold in medicinal chemistry, the story so far and perspectives. (Part 2): action in other targets and antitargets, Curr. Med. Chem. 19 (2012) 4306-4323 https://doi.org/10.2174/ 092986712802884204

[12] N.J. Ortner, G. Bock, A. Dougalis, M. Kharitonova, J. Duda, S. Hess, P. Tuluc, T. Pomberger, N. Stefanova, F. Pitterl, T. Ciossek, H. Oberacher, H.J. Draheim, P. Kloppenburg, B. Liss, J. Striessnig, Lower affinity of isradipine for L-type $\mathrm{Ca}(2+)$ channels during substantia nigra dopamine neuron-like activity: implications for neuroprotection in Parkinson's disease, J. Neurosci. 37 (2017) 6761-6777 https://doi.org/10.1523/JNEUROSCI.2946-16.2017.

[13] R. Budriesi, P. Ioan, A. Locatelli, S. Cosconati, A. Leoni, M.P. Ugenti, A. Andreani, R. Di Toro, A. Bedini, S. Spampinato, L. Marinelli, E. Novellino, A. Chiarini, Imidazo[2,1-b]thiazole system: a scaffold endowing dihydropyridines with selective cardiodepressant activity, J. Med. Chem. 51 (2008) 1592-1600 https://doi.org/10.1021/jm070681+.

[14] A. Locatelli, S. Cosconati, M. Micucci, A. Leoni, L. Marinelli, A. Bedini, P. Ioan, S.M. Spampinato, E. Novellino, A. Chiarini, A.R. Budriesi, Ligand based approach to L-type calcium channel by imidazo[2,1-b]thiazole-1,4-dihydropyridines: from heart activity to brain affinity, J. Med. Chem. 56 (2013) 3866-3877 https://doi.org/10.1021/jm301839q.

[15] A.P. Phillips, Hantzsch's pyridine synthesis, J. Am. Chem. Soc. 71 (1949) 4003-4007 https://doi.org/10.1021/ja01180a037.

[16] Ambinter Stock Screening Collection: Order Number: Amb3814428, CAS: 564442-65-5.

[17] G. Zoller, H. Strobel, D.W. Will, P. Wohlfart, Imidazo[2, 1-b]thiazoles and Their Use as Pharmaceuticals, 2006, WO2008058641A1.

[18] A. Andreani, M. Granaiola, A. Leoni, A. Locatelli, R. Morigi, M. Rambaldi, L. Varoli, D. Lannigan, J. Smith, D. Scudiero, S. Kondapaka, R.H. Shoemaker, Imidazo[2,1-b]thiazole guanylhydrazones as RSK2 inhibitors, Eur. J. Med. Chem. 46 (2011) 4311-4323 https://doi.org/10.1016/j.ejmech.2011.07.001.

[19] A. Andreani, M. Rambaldi, A. Locatelli, F. Andreani, 5-Formylimidazo[2,1-b]thiazoles and derivatives with herbicidal activity, Collect. Czechoslov. Chem. Commun. 56 (1991) 2436-2447 https://doi.org/10.1135/ cccc19912436.

[20] A. Andreani, D. Bonazzi, M. Rambaldi, Potential antitumor agents, VII. 5-Substituted 6-phenylimidazo[2,1-b]thiazoles, Arch. Pharm. (Weinheim) 315 (1982) $451-456$.

[21] A. Andreani, M. Rambaldi, A. Leoni, A. Locatelli, R. Bossa, M. Chiericozzi, L. Galatulas, G. Salvatore, Synthesis and cardiotonic activity of imidazo[2,1-b]thiazoles bearing a lactam ring, Eur. J. Med. Chem. 31 (1996) 383-387 https://doi. org/10.1016/0223-5234(96)89164-1.

[22] A. Andreani, M. Granaiola, A. Leoni, A. Locatelli, R. Morigi, M. Rambaldi, G. Giorgi, V. Garaliene, Potential antitumor agents. 34. Synthesis and antitumor activity of guanylhydrazones from imidazo[2,1-b]thiazoles and from diimidazo[1,2-a: 1,2-c] pyrimidine, Anticancer Res. 24 (2004) 203-211.

[23] A. Andreani, S. Burnelli, M. Granaiola, A. Leoni, A. Locatelli, R. Morigi, M Rambaldi, L. Varoli, G. Farruggia, C. Stefanelli, L. Masotti, M.W. Kunkel, Synthesis and antitumor activity of guanylhydrazones from 6-(2,4-dichloro-5-nitrophenyl)imidazo[2,1-b]thiazoles and 6-pyridylimidazo[2,1-b]thiazoles(1), J. Med. Chem. 49 (2006) 7897-78901 https://doi.org/10.1021/jm061077m.

[24] A. Andreani, M. Granaiola, A. Leoni, A. Locatelli, R. Morigi, M. Rambaldi, G. Lenaz, R. Fato, C. Bergamini, G. Farruggia, Potential antitumor agents. 37. Synthesis and antitumor activity of guanylhydrazones from imidazo[2,1-b]thiazoles and from the new heterocyclic system thiazolo[2',3':2,3]imidazo[4,5-c]quinoline, J. Med. Chem. 48 (2005) 3085-3089 https://doi.org/10.1021/jm040888s.

[25] A. Andreani, M. Rambaldi, A. Locatelli, R. Bossa, I. Galatulas, M. Ninci, Synthesis and cardiotonic activity of 2,5-dimethoxyphenylimidazo[2,1-b]thiazoles, Eur. J. Med. Chem. 27 (1992) 431-433 https://doi.org/10.1016/02235234(92)90159-X.

[26] R. Budriesi, P. Ioan, A. Leoni, N. Pedemonte, A. Locatelli, M. Micucci, A. Chiarini, L.J. Galietta, Cystic fibrosis: a new target for 4-Imidazo[2,1-b]thiazole-1,4-Dihydropyridines, J. Med. Chem. 54 (2011), 3885-3094 https://doi.org/ $10.1021 / \mathrm{jm} 200199 \mathrm{r}$.

[27] M.J. Berridge, Calcium signalling and Alzheimer's disease, Neurochem. Res. 36 (2011) 1149-1156 https://doi.org/10.1007/s11064-010-0371-4.

[28] D. Surmeier, Calcium, ageing, and neuronal vulnerability in Parkinson's disease, Lancet Neurol. 6 (2007) 933-938 https://doi.org/10.1016/S1474-4422(07)702466.

[29] C.S. Chan, T.S. Gertler, D.J. Surmeier, Calcium homeostasis, selective vulnerability and Parkinson's disease, Trends Neurosci. 32 (2009) 249-256 https://doi. org/10.1016/j.tins.2009.01.006

[30] V.S. Kumar, A. Gopalakrishnan, M. Naziroğlu, G.K. Rajanikant, Calcium ion--the key player in cerebral ischemia, Curr. Med. Chem. 21 (2014) 2065-2075 https://doi.org/10.2174/0929867321666131228204246.

[31] P.F. Copenhaver, T.S. Anekonda, D. Musashe, K.M. Robinson, J.M. Ramaker, T.L. Swanson, T.L. Wadsworth, D. Kretzschmar, R.L. Woltjer, J.F. Quinn, A translational continuum of model systems for evaluating treatment strategies in Alzheimer's disease: isradipine as a candidate drug, Dis. Model Mech. 4 (2011) 634-648 https://doi.org/10.1242/dmm.006841. 
[32] J.M. Simard, T.A. Kent, M. Chen, K.V. Tarasov, V. Gerzanich, Brain oedema in focal ischemia: molecular pathophysiology and theoretical implications, Lancet Neurol. 6 (2007) 258-268 https://doi.org/10.1016/S1474-4422(07)70055-8.

[33] H.J. Hu, M. Song, Disrupted ionic homeostasis in ischemic stroke and new therapeutic targets, J. Stroke Cerebrovasc. Dis. 26 (2017) 2706-2719 https://doi.org/ 10.1016/j.jstrokecerebrovasdis.2017.09.011.

[34] S. Lecht, E. Rotfeld, H. Arien-Zakay, R. Tabakman, H. Matzner, R. Yaka, P.I. Lelkes, P. Lazarovici, Neuroprotective effects of nimodipine and nifedipine in the NGF-differentiated PC12 cells exposed to oxygen-glucose deprivation or trophic withdrawal, Int. J. Dev. Neurosci. 30 (2012) 465-469 https://doi.org/10. 1016/j.ijdevneu.2012.05.007.

[35] S. Hashioka, A. Klegeris, P.L. McGeer, Inhibition of human astrocyte and microglia neurotoxicity by calcium channel blockers, Neuropharmacology 63 (2012) 685-691 https://doi.org/10.1016/j.neuropharm.2012.05.033.

[36] S.W. Jia, X.Y. Liu, S.C. Wang, Y.F. Wang, Vasopressin hypersecretion-associated brain edema formation in ischemic stroke: underlying mechanisms, $\mathrm{J}$. Stroke Cerebrovasc. Dis. 6 (2016) 1289-1300 https://doi.org/10.1016/j. jstrokecerebrovasdis.2016.02.002.

[37] J. Striessnig, N.J. Ortner, A. Pinggera, Pharmacology of L-type calcium channels: novel drugs for old targets?, Curr. Mol. Pharmacol. 8 (2015) 110-122 https://doi.org/10.2174/1874467208666150507105845.

[38] T.S. Anekonda, J.F. Quinn, Calcium channel blocking as a therapeutic strategy for Alzheimer's disease: the case for isradipine, Biochim. Biophys. Acta 12 (2011) 1584-1590 https://doi.org/10.1016/j.bbadis.2011.08.013.

[39] ClinicalTrials NCT02168842: Efficacy of Isradipine in Early Parkinson Disease.

[40] G. Tenti, E. Parada, R. León, J. Egea, S. Martínez-Revelles, A.M. Briones, V. Sridharan, M.G. López, M.T. Ramos, J.C. Menéndez, New 5-unsubstituted dihydropyridines with improved Cav1.3 selectivity as potential neuroprotective agents against ischemic injury, J. Med. Chem. 57 (2014) 4313-4323 https://doi. org/10.1021/jm500263v.

[41] A. Schampel, O. Volovitch, T. Koeniger, C.J. Scholz, S. Jörg, R.A. Linker, E. Wischmeyer, M. Wunsch, J.W. Hell, S. Ergün, S. Kuerten, Nimodipine fosters remyelination in a mouse model of multiple sclerosis and induces microglia-specific apoptosis, Proc. Natl. Acad. Sci. U.S.A. 16 (2017) 3295-3304 https://doi. org/10.1073/pnas.1620052114
[42] M. Hu, Z. Liu, P. Lv, H. Wang, Y. Zhu, Q. Qi, J. Xu, L. Gao, Nimodipine activates neuroprotective signaling events and inactivates autophages in the VCID rat hippocampus, Neurol. Res. 10 (2017) 904-909 https://doi.org/10.1080/ 01616412.2017.1356157.

[43] S. Gupta, U. Sharma, N.R. Jagannathan, Y.K. Gupta, Neuroprotective effect of lercanidipine in middle cerebral artery occlusion model of stroke in rats, Exp. Neurol. 288 (2017) 25-37 https://doi.org/10.1016/j.expneurol.2016.10.014

[44] S.M. Berger, D. Bartsch, The role of L-type voltage-gated calcium channels Cav1.2 and Cav1.3 in normal and pathological brain function, Cell Tissue Res. 357 (2014) 463-476 https://doi.org/10.1007/s00441-014-1936-3.

[45] J.H. Weiss, D.M. Hartley, J. Koh, D.W. Choi, The calcium channel blocker nifedipine attenuates slow excitatory amino acid neurotoxicity, Science 247 (1990) 1474-1477 https://doi.org/10.1126/science.2157282.

[46] C. Santulli, C. Brizi, M. Micucci, A. Del Genio, A. De Cristofaro, F. Bracco, G.L. Pepe, I. Di Perna, R. Budriesi, A. Chiarini, M. Frosini, Castanea sativa mill. Bark extract protects U-373 MG cells and rat brain slices against ischemia and reperfusion injury, J. Cell. Biochem. 11 (2017) 839-850 https://doi.org/10.1002/ jcb. 25760 .

[47] C. Brizi, C. Santulli, M. Micucci, R. Budriesi, A. Chiarini, C. Aldinucci, M. Frosini, Neuroprotective effects of castanea sativa mill. Bark extract in human neuroblastoma cells subjected to oxidative stress, J. Cell. Biochem. 117 (2016) 510-520 https://doi.org/10.1002/jcb.25302.

[48] J. O'Brien, I. Wilson, T. Orton, F. Pognan, Investigation of the Alamar Blue (resazurin) fluorescent dye for the assessment of mammalian cell cytotoxicity, Eur. J. Biochem. 267 (2000) 5421-5426 https://doi.org/10.1046/j.1432-1327.2000. 01606.x.

[49] A. Contartese, M. Valoti, F. Corelli, S. Pasquini, C. Mugnaini, F. Pessina, C. Aldinucci, G. Sgaragli, M. Frosini, A novel CB2 agonist, COR167, potently protects rat brain cortical slices against OGD and reperfusion injury, Pharmacol. Res. 66 (2012) 555-563 https://doi.org/10.1016/j.phrs.2012.08.003.

[50] L. Ricci, M. Valoti, G. Sgaragli, M. Frosini, Neuroprotection afforded by diazepam against oxygen/glucose deprivation-induced injury in rat cortical brain slices, Eur. J. Pharmacol. 561 (2007) 80-84 https://doi.org/10.1016/j.ejphar. 2006.12.030. 